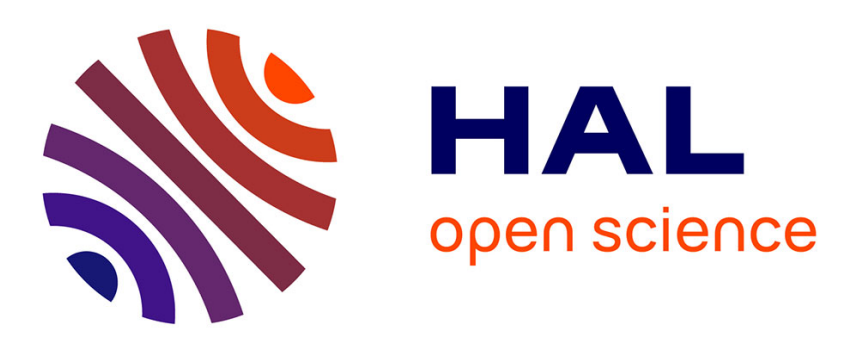

\title{
Marine and subaerial controls of coastal chalk cliff erosion in Normandy (France) based on a 7-year laser scanner monitoring
}

Pauline Letortu, Stéphane Costa, Olivier Maquaire, Robert Davidson

\section{- To cite this version:}

Pauline Letortu, Stéphane Costa, Olivier Maquaire, Robert Davidson. Marine and subaerial controls of coastal chalk cliff erosion in Normandy (France) based on a 7-year laser scanner monitoring. Geomorphology, 2019, 335, pp.76-91. 10.1016/j.geomorph.2019.03.005 . hal-02051396

\section{HAL Id: hal-02051396 https://hal.science/hal-02051396}

Submitted on 15 Dec 2020

HAL is a multi-disciplinary open access archive for the deposit and dissemination of scientific research documents, whether they are published or not. The documents may come from teaching and research institutions in France or abroad, or from public or private research centers.
L'archive ouverte pluridisciplinaire HAL, est destinée au dépôt et à la diffusion de documents scientifiques de niveau recherche, publiés ou non, émanant des établissements d'enseignement et de recherche français ou étrangers, des laboratoires publics ou privés. 


\section{Marine and Subaerial Controls of Coastal Chalk Cliff Erosion in Normandy (France)}

Based on a 7-year Laser Scanner Monitoring

Pauline Letortu ${ }^{a^{*}}$, Stéphane Costa ${ }^{\mathrm{b}}$, Olivier Maquaire ${ }^{\mathrm{b}}$, and Robert Davidson ${ }^{\mathrm{b}}$

aUniversity of Bretagne Occidentale, CNRS, UMR LETG, IUEM, Rue Dumont d'Urville, Plouzané, 29280, France; pauline.letortu@univ-brest.fr

${ }^{b}$ Normandie Univ, UNICAEN, CNRS, UMR LETG, Esplanade de la Paix, Caen, 14000, France; stephane.costa@unicaen.fr, olivier.maquaire@unicaen.fr, robert.davidson@unicaen.fr

* Corresponding author. Tel.: +33 290915588, pauline.letortu@univ-brest.fr

Abstract:

Between October 2010 and November 2017, surveys using terrestrial laser scanning (TLS) were carried out every 4-5 months to monitor erosion on three chalk cliff faces with close structural characteristics in Normandy (the two Dieppe sites are abandoned cliffs while the Varengeville-sur-Mer site is an active one). The uniqueness of this paper is the comparison between these cliff sections and the significance of marine and/or subaerial controls in erosion. Beyond the quantification of annual retreat rates, which on the active cliff are currently 36 times greater than on the abandoned cliffs, this paper highlights the fundamental efficacy of marine controls in the current cliff erosion and the removal of falls (analyses of modalities of retreat and profile evolution according to a naturalistic approach). Subaerial processes appear to have a less erosive action than marine ones, because the studied abandoned cliffs show low erosion dynamics and have maintained a subvertical profile despite continentalization for between 30 to more than 120 years.

Keywords: Marine processes; Subaerial processes; Cliff erosion; Terrestrial laser scanning (TLS). 


\section{Introduction}

The retreat rates, the modalities of erosion (frequency, intensity, and spatial distribution), and the cliff profile depend on the morpho-structural conditions and the efficacy of marine and subaerial agents and processes (Emery and Kuhn, 1982). Improving understanding of erosion is necessary because coastal cliff dynamics are inherently non-linear. Nothing happens for several years and suddenly a fall can occur and may cause fatalities and damage to infrastructure close to cliff line. One of the challenges in the research is to foresee coastal evolution to ensure the resiliency of coastal communities (e.g. Gilham et al., 2018). Research contributions into the dynamics of rocky coasts in recent years allow for a better understanding of retreat rates in a variety of locations worldwide (Brooks and Spencer, 2010; Bezore et al., 2016; Sajinkumar et al., 2017; Young, 2018), the identification of factors responsible for erosion (for a review, Kennedy et al., 2014a) and of some precursor signs before failure (Rosser et al., 2007), but knowledge of the respective contributions of triggering factors responsible for erosion are still difficult to determine (Costa, 2005; Naylor et al., 2010; Lim et al., 2011; Kuhn and Prüfer, 2014; Letortu et al., 2015a) even though some research has been successful in prioritizing factors (Bernatchez and Dubois, 2008; Bernatchez et al., 2011). In the northeastern part of Normandy (NW France), along the Channel, the plateaus of the Parisian Basin abruptly end in subvertical cliffs made up of Upper Cretaceous chalk with flint bands. The cliff line in Seine-Maritime had an average retreat rate of $0.15 \mathrm{~m} /$ year between 1966 and 2008 (Letortu et al., 2014) and has been increasingly monitored for a better understanding of erosion (e.g. Prêcheur, 1960; Evrard and Sinelle, 1987; Costa, 1997; Hénaff et al., 2002; Costa et al., 2004; Mortimore et al., 2004b; Regard et al., 2012; Rohmer and Dewez, 2013 ; Letortu et al., 2015b). On this chalky coast, there is a broad consensus on the role of lithological control and intense rainfall events as the main drivers of erosion. The trigger for falls often coincides with heavy winter rainfall (Duperret et al., 2002; Letortu et al., 2015a) particularly during wet years that cause the water table to rise in the chalky massif (Lageat et al., 2006) or during heavy rainfall during 
dry periods (Duperret et al., 2004). However, a significant erosion factor on both the cliff and shore platform is the role of freeze/thaw cycles (Moses et al., 2006; Dewez et al., 2015; Letortu et al., 2015a). Lageat et al. (2006) concluded that subaerial processes were the main processes responsible for the triggering of chalk cliff falls on the French Channel coast and that marine influence was limited to the removal of falls. This has been questioned in recent years because numerous researchers have highlighted the role of marine factors, both as an eroding agent and as a removal agent to reactivate erosion (Hénaff et al., 2002; Earlie et al., 2015; Letortu et al., 2015a; 2015b). To feed the debate, our previous research used statistical analyses (adjustment to power law scaling (Letortu et al., 2014) and multivariate analysis as PCA) and empirical analyses to identify the triggers of coastal chalk cliff failure based on an inventory of 331 rock falls collected weekly between 2002 and 2009 from Veules-les-Roses to Le Tréport ( $37.5 \mathrm{~km}$, Seine-Maritime). The results highlighted that 'cold and dry weather', 'high rainfall and high wind' are the conditions most likely to trigger rock falls (Letortu et al., 2015a). To go one step further and identify the dominance of marine or subaerial forcing, the current research analyzes retreat rates, modalities of retreat (frequency, intensity, and spatial distribution) and cliff profile evolution based on a 7-year monitoring project using Terrestrial Laser Scanning (TLS) of three cliff faces with close structural characteristics (lithology, stratigraphy, and tectonics) but different exposures to marine processes (abandoned and active cliffs).

\section{Study area}

\subsection{Regional settings}

The study area is of three Norman cliff sections along the Channel (Seine-Maritime): one cliff face in Varengeville-sur-Mer and two others in Dieppe (Fig. 1). The climate is a marine temperate west coast climate with mild temperatures throughout the year $\left(4.9^{\circ} \mathrm{C}\right.$ in January and $16.9^{\circ} \mathrm{C}$ in August according to Météo-France (1971-2000)). Temperatures in winter are positive (the coldest month is January with $4.9^{\circ} \mathrm{C}$ ) but freeze/thaw cycles can be numerous (an average of 26 daily freeze/thaw cycles per year) and frost can be intense (up to $-15^{\circ} \mathrm{C}$ ). 
Rainfall occurs throughout the year (about $800 \mathrm{~mm}$ ) but the wettest month is November, with $93.8 \mathrm{~mm}$, and the driest is August, with $50.6 \mathrm{~mm}$. However, in August, thunderstorms may occur and lead to a maximum daily rainfall of $100.8 \mathrm{~mm}$. Wind is frequent with a total of 102.8 days per year with gusts greater than or equal to $16 \mathrm{~m} / \mathrm{s}$, especially in December and January. The average tidal range is $8 \mathrm{~m}$ and swell is limited. However, wave height due to wind sea can reach $4 \mathrm{~m}$ in Dieppe (annual return period) (Augris, 2004).

The topography of the Seine-Maritime is characterized by the Pays de Caux plateau (average altitude of $150 \mathrm{~m}$ ) extending to the Channel, an Upper Cretaceous cliff line made up with chalk with flint bands, oriented SW/NE. This plateau is dissected by valleys and dry valleys. The valleys are quite wide (kilometer extent) and are former alluvial plains. This plateau presents different deformations with a succession of anticlines and synclines, in a NW/SE direction (Armorican direction), sometimes prolonged by flexures and faults (Cavelier et al., 1979; Mégnien and Mégnien, 1980; Cazes et al., 1985; Pomerol and Feugueur, 1986; Cavelier and Lorenz, 1987) (Fig. 1). A topographic saddle, which corresponds to the northwestern termination of the "Norman gutter" (the exhumed anticlinal inlier of the Pays de Bray, in the hinterland of Dieppe, constitutes a geographical entity that extends south to Picardy) follows the syncline of the Vexin and extends to that of the Scie.

Cliffs from cap d'Antifer to Le Tréport (100 km) have an average height of $60-70 \mathrm{~m}$ but the structural variations explain the variations of height (from $20 \mathrm{~m}$ to more than $100 \mathrm{~m}$; Fig. 1) of chalk stage outcrop (from the oldest to the newest stages: Cenomanian, Turonian, Coniacian, Santonian and Campanian). The subtle resistance contrasts of chalk outcrop explain different profiles of the cliffs (Pomerol et al., 1987; Costa, 1997; Mortimore et al., $2004 b$ ) and mostly explain the high spatial variability of the retreat rates (from 0.09 to 0.23 m/year ( \pm 0.03 m/an; 1966-1995-2008)) obtained by photo-interpretation (Costa et al., 2004; Letortu et al., 2014). The retreat rate is the highest where, above Santonian and Campanian chalk strata, the residual flint formation (Pomerol et al., 1987; Laignel, 1997; Costa et al., 2004) has been replaced by a bed of clay and sand sediments about 10-30 m thick from the 
Paleogene period (Bignot, 1962). This bed is mainly along the cap d'Ailly (Sainte-Marguerite-

113 sur-Mer, Varengeville-sur-Mer), and Sotteville-sur-Mer (Fig. 1).

114 The pre-existing fracture network influences the rock mass strength and the mode of failure

115 (Middlemiss, 1983; Evrard and Sinelle, 1987; Duperret et al., 2004; Mortimore et al., 2004a).

116 The dominant fracture set collected on the cliff face and on the shore platform is N110-

117 N130E followed by N025E (Evrard and Sinelle, 1987; Genter et al., 2004; Costa et al.,

118 2006b). Genter et al. (2004) highlight the N110-130E fracture set is almost ubiquitous

119 throughout the Norman chalk coastline, made mainly of master-joints (large nearly vertical

120 fractures that cross the whole cliff with an apparent extension of tens to hundreds of metres)

121 and normal faults (typical apparent vertical offsets of $\mathrm{cm}$ to metre scale). Movements of

122 various magnitudes (from a few $\mathrm{m}^{3}$ to hundreds of thousands of $\mathrm{m}^{3}$ ) are a ubiquitous

123 phenomenon along the Seine-Maritime coastline.

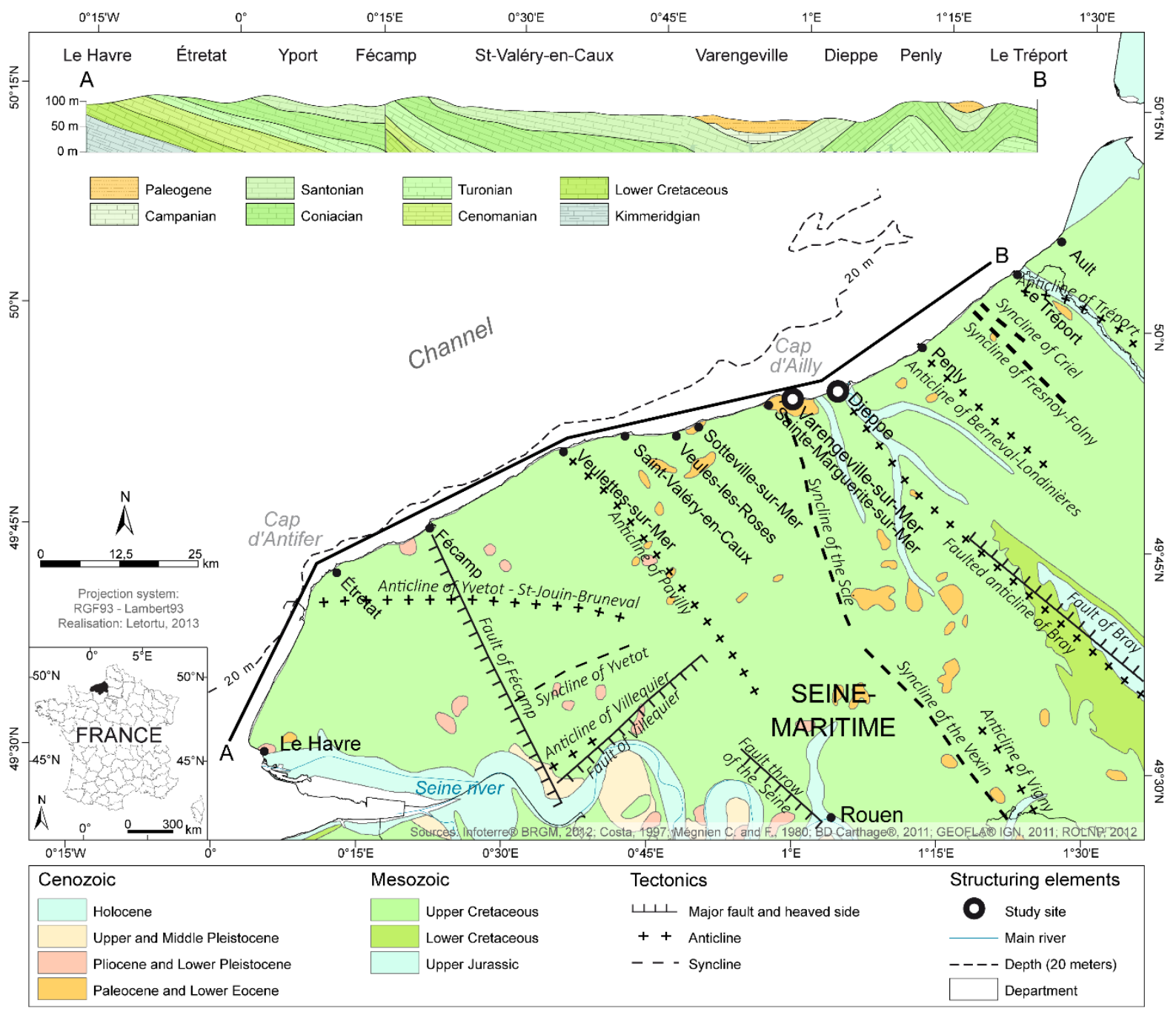


Fig. 1: Geological and structural framework in Seine-Maritime (Normandy) and the location of the studied sites. For interpretation of the references to color in this figure, the reader is referred to the web version of this article.

At the cliff foot, the shore platform has a fairly homogeneous appearance with a rocky surface and is slightly inclined towards the sea (from $0.2 \%$ gradient at Le Tréport to $2 \%$ at cap d'Antifer). Its width is between 100 and $750 \mathrm{~m}$. In contact with the cliff foot and the shore platform, the average width of the gravel beach is about $15-20 \mathrm{~m}$, with a thickness of 2-3 $\mathrm{m}$. At the valley outlets, where they are supported by longitudinal sea defense structures (dikes and piers), their width may exceed $100 \mathrm{~m}$ and their thickness $11 \mathrm{~m}$ at the Dieppe jetty (Costa et al., 2006a).

\subsection{Site selection}

The active cliff at Varengeville-sur-Mer is along the cap d'Ailly (6 km from Dieppe) (Fig. 2a), on either side of the Petit Ailly dry valley. This cliff is $250 \mathrm{~m}$ long, $40 \mathrm{~m}$ high, facing $010^{\circ} \mathrm{N}$, with a subvertical profile (from $70^{\circ}$ to overhang). The historical annual retreat rate is of 0.38 m/year (1966-2008 from Letortu et al., 2014).

The abandoned cliffs at Dieppe are located on the right bank of the Arques river mouth, behind an extension of the northeastern part of the harbor, land reclaimed from the sea. Dieppe $1 \mathrm{~W}$ is $45 \mathrm{~m}$ long, $35 \mathrm{~m}$ high, facing $310^{\circ} \mathrm{N}$, with a subvertical profile. This cliff, in front of the Newhaven-Dieppe ferry port, has a historical annual retreat rate of $0.04 \mathrm{~m} /$ year (19662008 from Letortu et al., 2014). Dieppe $2 \mathrm{~N}$ is $80 \mathrm{~m}$ long, $35 \mathrm{~m}$ high, facing $010^{\circ} \mathrm{N}$, with a subvertical profile. The historical annual retreat rate of Dieppe $2 \mathrm{~N}$ is of $0.06 \mathrm{~m} / \mathrm{year}$ (19662008 from Letortu et al., 2014). Dieppe $1 \mathrm{~W}$ became abandoned during the nineteenth century whereas Dieppe $2 \mathrm{~N}$ became abandoned in the 1980s (Fig. 2a). 

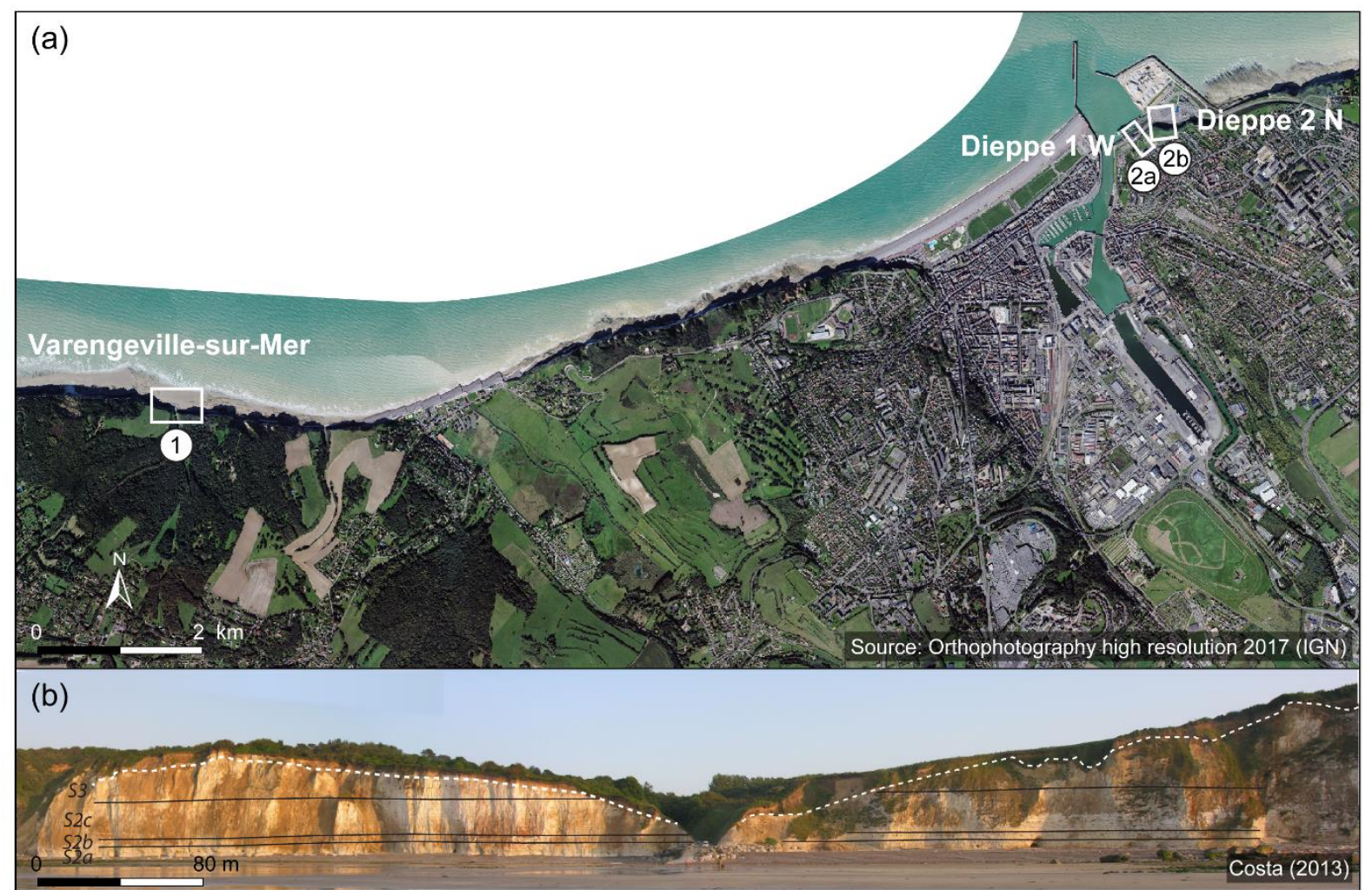

(1) Santonian chalk and Tertiary strata (above the white dotted line); $\mathrm{L} \approx 250 \mathrm{~m} ; \mathrm{H} \approx 40 \mathrm{~m} ; 010^{\circ} \mathrm{N}$

S2a,b,c: lower, middle and upper part of Middle Santonian (Seaford Chalk); S3: Upper Santonian (Newhaven Chalk) adapted by Hoyez (2008) from Mortimore (2001).

(c)

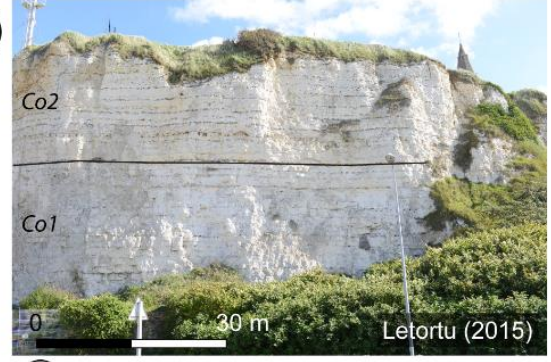

(2a) Coniacian chalk; $\mathrm{L} \approx 45 \mathrm{~m} ; \mathrm{H} \approx 35 \mathrm{~m}, 310^{\circ} \mathrm{N}$

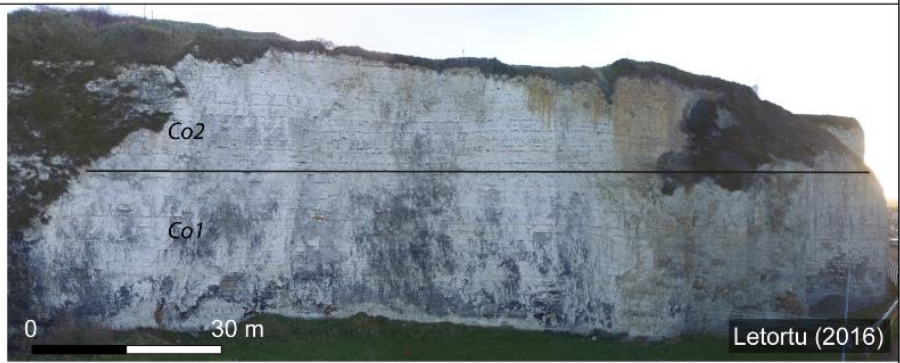

(2b) Coniacian chalk; $\mathrm{L} \approx 80 \mathrm{~m} ; \mathrm{H} \approx 35 \mathrm{~m} ; 010^{\circ} \mathrm{N}$

Co1: Lower Coniacian (Lewes Chalk); Co2: Middle Coniacian (Seaford Chalk) adapted by Hoyez (2008) from Mortimore (2001).

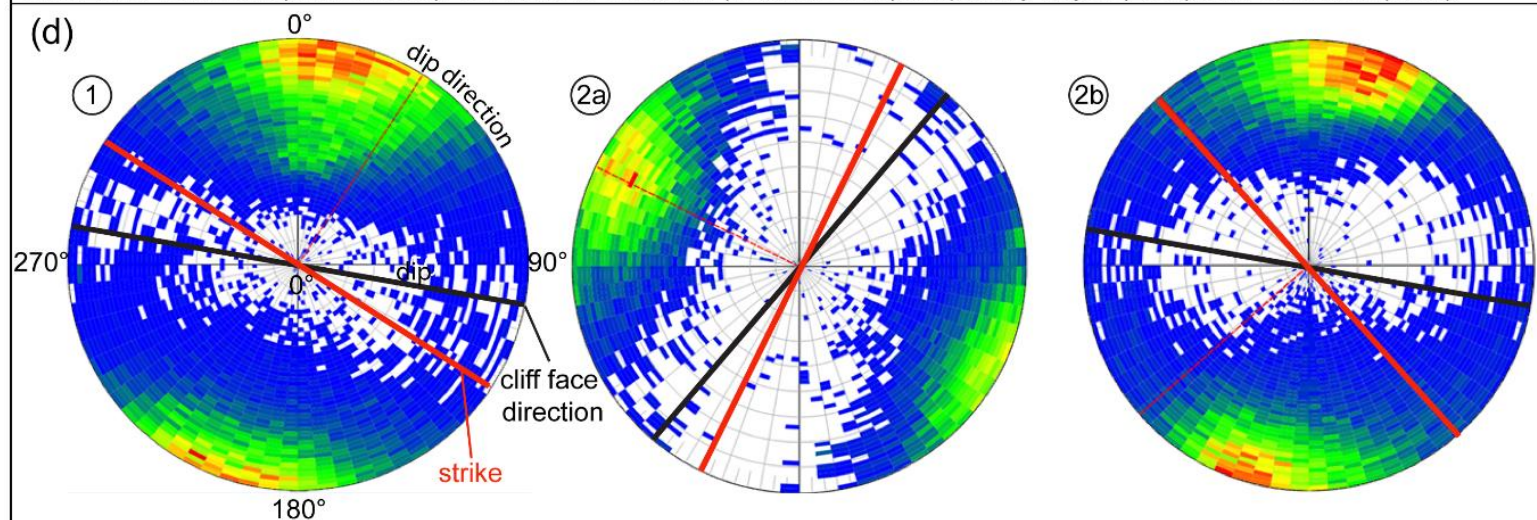

Stereograms of facets extracted with FACETS in Cloudcompare ${ }^{8}$ from the first $3 D$ point cloud of each site (Dewez et al., 2016).
(e)
- Varengeville-sur-Mer $\bullet$ Dieppe

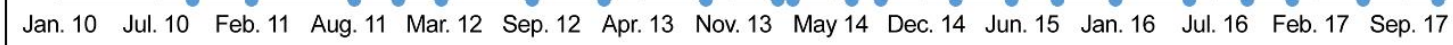


Fig. 2: (a) Location of the sites; (b) Main characteristics of Varengeville-sur-Mer site (Chalk

153

154

155

156

157

158

159

160

161

162

163

164

165

166

167

Formations are adapted by Hoyez (2008) from Mortimore (2001)); (c) Main characteristics of Dieppe sites (Chalk Formations are adapted by Hoyez (2008) from Mortimore (2001)); (d) Stereograms of each cliff section (planar facets with their strike, dip and dip direction) extracted with FACETS in Cloudcompare® (Dewez et al., 2016); (e) Temporal distribution of the TLS surveys.

The site at Varengeville-sur-Mer is on the Scie syncline (at $6 \mathrm{~km}$ west of the faulted Bray anticline) and the sites of Dieppe are connected to the eastern part of Bray fault (Fig. 1). The cliff lithology at Varengeville is made up of Santonian chalk, covered by a bed of clay and sand of Paleogene period (due to the syncline prone strata preservation). Clay and sand are very prone to erosion (Fig. 2b). The cliff section of Dieppe is made up of Coniacian chalk covered with residual flint formation (Fig. 2c). Even if each facies within a stage has some subtle resistance contrasts, the Coniacian chalk is close to the physical and lithological characteristics of Santonian chalk (Laignel, 2003) (Table 1). However, Coniacian chalk is less fine, rougher to the touch than Santonian, with conglomeratic, yellowish and hardened chalk beds that are a little more numerous (Auffret and Bignot, 1978).

Table 1: Physical and lithological characteristics of the Coniacian and Santonian chalk stages of the western part of the Parisian Basin (Laignel, 2003)

\begin{tabular}{|c|l|c|c|c|}
\hline \multicolumn{1}{|c|}{ Stage } & \multicolumn{1}{|c|}{ Facies } & Porosity \% & $\begin{array}{c}\text { Permeability } \\
\text { millidarcy }\end{array}$ & Density \\
\hline \multirow{3}{*}{ Coniacian } & white chalk (dominant facies) & & & $1.6-1.7$ \\
& whitish chalk, slighty clayey (mainly at the base) & $22.6-38.3$ & $1.1-2.6$ & $1.8-1.9$ \\
& nodular chalk (mainly at the base) & & & $1.9-2.4$ \\
\hline \multirow{2}{*}{ Santonian } & white chalk & $40.2-45.6$ & $3.5-5.6$ & $1.6-1.8$ \\
& nodular chalk (very rare) & & $1.9-2.2$ \\
\hline
\end{tabular}

In the studied sites, the regional set (N110-N130E) is apparent in the stereograms, with master joints at Varengeville-sur-Mer and Dieppe $2 \mathrm{~N}$ (Fig. 2d). In Dieppe $1 \mathrm{~W}$, the strike is about N025E, which is the secondary fracture set observed by Genter et al. (2004). The 
bedding dips are very low (0.5-1\%) (Bignot, 1971).These fracture orientations and lithology result in falls with a dominant vertical failure type in the three sections. Infrequently, sliding failure type might occur in Varengeville-sur-Mer between Lower-Middle Santonian and Upper Santonian (Duperret et al., 2004).

In contact with the Bray faulted anticline (Fig. 1) the fracturing is high. Genter et al. (2004) measured, for the total of fracture types, a mean spacing between fractures of $5-10 \mathrm{~m}$ for the eastern part of Dieppe, against 15-20 m in Varengeville-sur-Mer. Fracturing difference may impact on rates and modalities of retreat due to "pre-cutting" of the cliff but, according to Duperret et al. (2004), the empirical relationship between numerous falls and intense fracturing is not systematic probably because the natural fracture properties and the interaction with other parameters may be more complex. Indeed, the higher value of fractures in Dieppe (5-10 m) than in Varengeville $(15-20 \mathrm{~m})$ does not lead to higher historical annual retreat rates. Besides, subtle differences in resistance between both stages cannot explain such contrasting regressive dynamics. This is explained by the efficacy (or inefficacy) of the external erosion forcing.

The studied cliff faces are characterized by: (1) Coniacian and Santanian chalk stages prone to erosion; (2) two contexts - Varengeville is an active cliff (marine and subaerial processes act together) and Dieppe is an abandoned cliff (action of subaerial processes only); (3) their proximity (distance of $6 \mathrm{~km}$ ), assuming weather conditions are similar; (4) their verticality (from $75^{\circ}$ to overhang), their height (35-40 m) and the linearity of the coastline; and (5) their spatial extent (from $45 \mathrm{~m}$ long in Dieppe to $250 \mathrm{~m}$ long in Varengeville-sur-Mer).

\section{Material and methods}

\subsection{TLS surveys}

A terrestrial laser scanner is an optical active remote-sensing technology. The two-way time of flight of a laser pulse reflected by a point is used to measure the point position (range and angles) relative to the device. The laser beam covers the environment with vertical scanning by an oscillating mirror and horizontal scanning by rotating the head. This instrument is 
widely used and numerous applications of the TLS technique on slope instabilities are given by the review of Abellán et al. (2014).

In Varengeville-sur-Mer, the two scanner stations are positioned on the foreshore at about 75 m from the cliff face (Fig. 3). In Dieppe, the two scanner stations are precisely positioned on the ground at a horizontal distance of $33 \mathrm{~m}$ (Dieppe $1 \mathrm{~W}$ ) and $37 \mathrm{~m}$ (Dieppe $2 \mathrm{~N}$ ) from the subvertical cliff face respectively. The site configuration and the survey design (with one target and a Trimble M3 total station) reduce occlusion and poor incident angles and enable large spatial coverage with a very high resolution (median spacing from $0.02 \mathrm{~m}$ in Dieppe to $0.05 \mathrm{~m}$ in Varengeville-sur-Mer). TLS survey is described in detail in Letortu et al. (2015b; 2018).

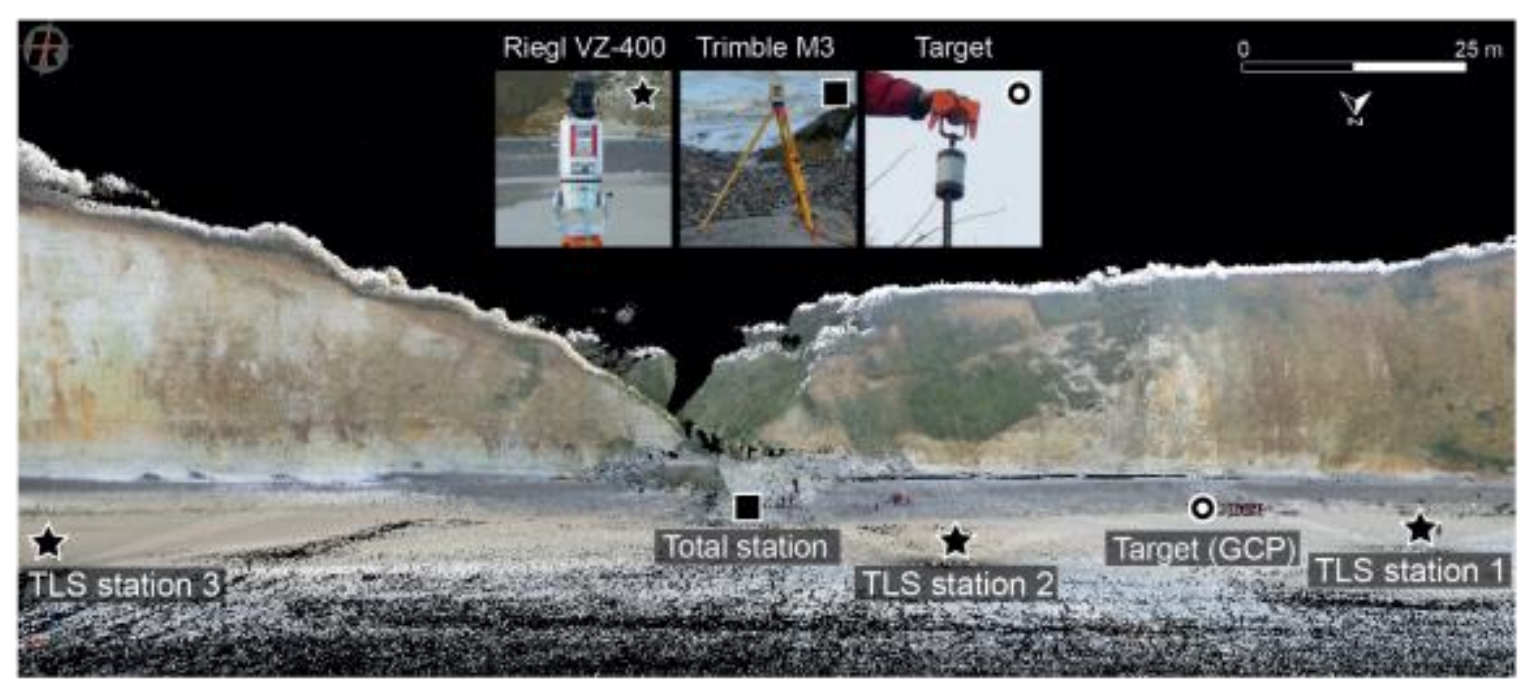

Fig. 3: Description of the instruments used for the cliff face erosion monitoring (survey of 2017/11/02 in Varengeville-sur-Mer).

Since October 2010, 21 diachronic surveys have been performed in Varengeville-sur-Mer and 19 in each of Dieppe sites (every 4-5 months, $2 \mathrm{~h}$ per site by 3 people; Fig. 2e). Stabilization work on both cliff faces in Dieppe in February 2013 reduced the length of the studied areas due to rock protection meshes set up on the cliff face (from $45 \mathrm{~m}$ to $25 \mathrm{~m}$-long for Dieppe $1 \mathrm{~W}$, from $80 \mathrm{~m}$ to $45 \mathrm{~m}$-long for Dieppe $2 \mathrm{~N}$ ). 


\subsection{Data processing and error margin}

Data processing has 4 steps: (1) georeferencing and point cloud alignment; (2) manual point cloud filtering (vegetation, people, foreshore); (3) meshing using Delaunay triangulation and generation of a 3D Digital Elevation Model (DEM); and (4) creating a DEM of Difference (DoD).

Precision is the most important parameter in our monitoring, thus all the point clouds are fitted to the 6 July 2011 reference point cloud using best fit alignment algorithms (Cloudcompare ${ }^{\circledR}$ or 3DReshaper $\left.{ }^{\circledR}\right)$. This adjustment reduces the error margin because it includes the TLS instrumental error and the cloud adjustment error (fitting) only. To assess precision, fixed parts of the point cloud are compared using the usual data processing. The precision in planimetry is $0.03 \mathrm{~m}$ for Varengeville-sur-Mer and Dieppe $2 \mathrm{~N}$ and $0.02 \mathrm{~m}$ for Dieppe $1 \mathrm{~W}$. The volume precision is $\pm 156 \mathrm{~m}^{3}$ in Varengeville-sur-Mer (surface of $5214 \mathrm{~m}^{2}$ ), $\pm 9 \mathrm{~m}^{3}$ in Dieppe $1 \mathrm{~W}\left(434 \mathrm{~m}^{2}\right)$ and $\pm 30 \mathrm{~m}^{3}$ in Dieppe $2 \mathrm{~N}\left(1018 \mathrm{~m}^{2}\right)$.

Some disturbances occurred during data acquisition such as temporary ground vibrations due to the docking of a cross channel ferry (2011/07/06 and 2013/02/12 in Dieppe $1 \mathrm{~W})$ or scanner sinking in wet sand (2011/02/24 and 2015/02/26 in Varengeville-sur-Mer). Thus, these four point clouds have artifacts and they are not used to quantify the rate of retreat, but are retained to study the spatial distribution of material departures (dates in gray in Fig. 6). In February 2013, stabilization work was carried out in Dieppe. These consisted of clearing hazardous parts of the cliff (human erosion in Fig. 5) and setting up safety nets. To monitor the natural evolution of the cliff, these human activities are not considered in the calculations.

\subsection{Data analysis}

This 3D dataset allows the analysis of different characteristics of the cliff face evolution such as the eroded surface and volume, calculations of retreat rates, the modalities of retreat and the profile evolution. Emery and Kuhn (1982) present the profile of active cliffs as an indicator of the power balance between the resistance and homogeneity of the material outcropping 
on the cliff face and the combined aggressiveness of marine and subaerial agents (including ground water) associated with gravity. A steep slope at the foot of a cliff generally indicates dominance of marine erosion, while a gentle slope at the base means that subaerial erosion dominates. This classification has been included in numerous publications (e.g. Kuhn and Prüfer, 2014) and is used in this paper to identify, from a geomorphological point of view, the dominant forcing on erosion of the studied cliffs.

\section{Results}

\subsection{Annual retreat rates}

Unsurprisingly, the wave-battered cliff currently retreats faster than the abandoned ones but with a significant difference: 36 times faster than Dieppe $2 \mathrm{~N}$. The annual retreat rate is 0.36 $\mathrm{m} /$ year in Varengeville-sur-Mer (13366 $\pm 156 \mathrm{~m}^{3}$ fell in 85 months over $5214 \mathrm{~m}^{2}$, thus an average fall volume of $1887 \mathrm{~m}^{3} /$ year). It is $0.00 \mathrm{~m} /$ year in Dieppe $1 \mathrm{~W}\left(2 \mathrm{~m}^{3} \pm 9 \mathrm{~m}^{3}\right.$ fell in 85 months over $434 \mathrm{~m}^{2}$, thus an average fall volume of $0.3 \mathrm{~m}^{3} / \mathrm{year}$ ) and $0.01 \mathrm{~m} /$ year in Dieppe $2 \mathrm{~N}\left(14 \mathrm{~m}^{3} \pm 30 \mathrm{~m}^{3}\right.$ fell in 85 months over $1018 \mathrm{~m}^{2}$, thus an average fall volume of $2 \mathrm{~m}^{3} /$ year $)$ (Fig. 4). Despite the very high precision of the method presented in this study, this quantitative assessment may not be representative for the abandoned cliffs because erosion results are below the margin of error. However, these annual retreat rates on the cliff face observed by TLS over seven years are close to those observed by the cliff top photointerpretation between 1966 and 2008 (Letortu et al., 2014) with 0.38 m/year in Varengeville and 0.04-0.06 m/year in Dieppe. Taking into account the error margin of $\pm 0.03 \mathrm{~m} / \mathrm{year}$ of the photo-interpretation method, the 2010-2017 TLS results seem to be representative of the historical retreat rate values (42 years, 1966-2008). 


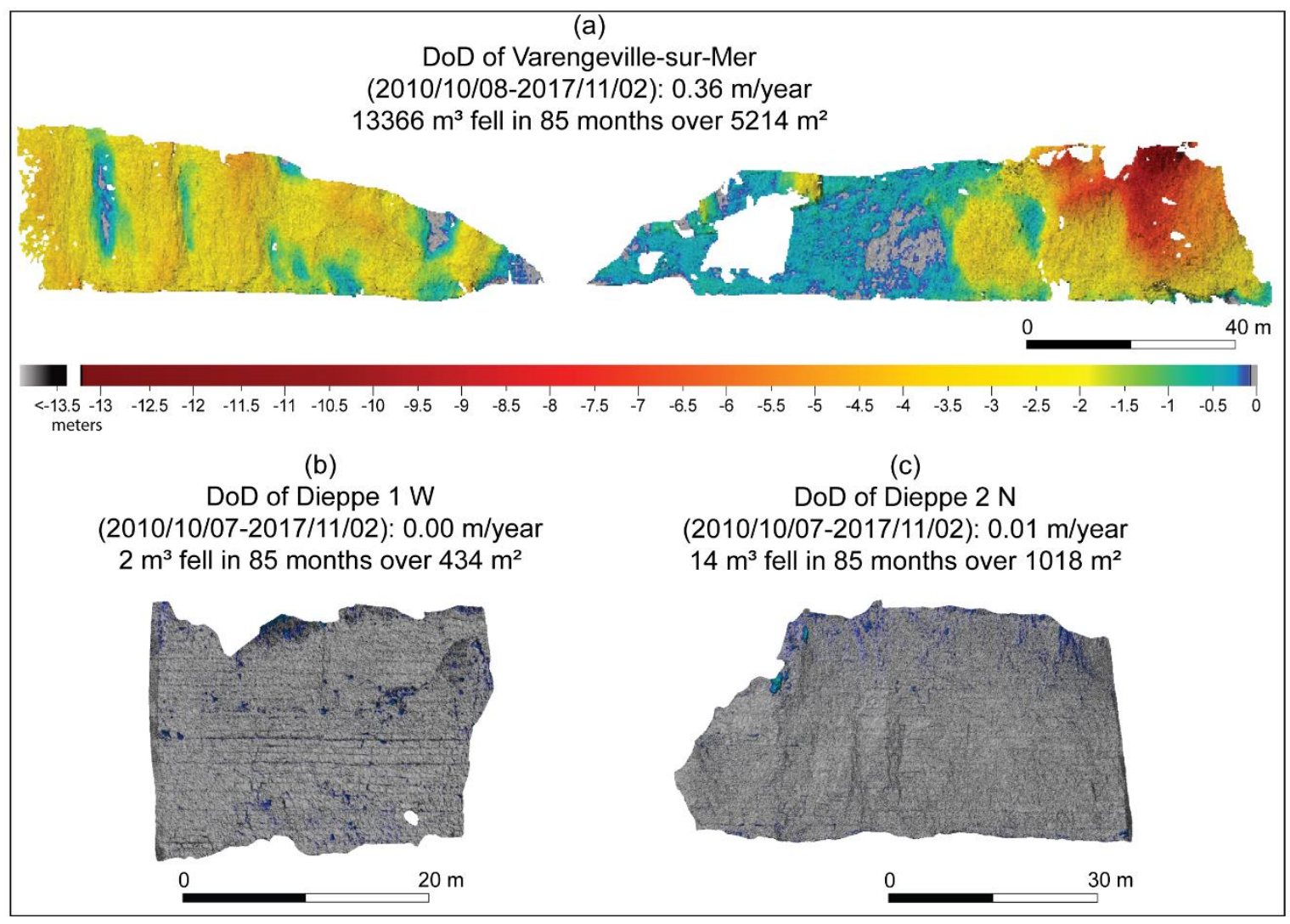

Fig. 4: Erosion results of DoD over 7 years of monitoring at each of the sites. For interpretation of the references to color in this figure, the reader is referred to the web version of this article.

\subsection{Retreat modalities and the responsible forcing}

Whereas erosion occurs almost everywhere on the cliff face in Varengeville-sur-Mer, erosion is rare and localized on the cliff face in Dieppe (Fig. 4). The patterns of erosion are different between sites. According to the classification of slope movements by Varnes in 1978 (which was updated by Dikau et al. (1996) and Hungr et al. (2014)), two terms can be used to describe movements of coherent rock in relation to fallen volume. Debris fall is used where tiny blocks or flakes (up to a decimeter) fall from across the cliff face, and rock fall is used to describe large-scale movements that fall from all or part of the cliff face. The abandoned cliffs of Dieppe are only affected by debris falls (Fig. 5, dark blue) over the 7year period. However, research in local newspapers between 1950 and 2010 reported that

291 rock falls had already occurred on the studied abandoned cliffs. In March 2001, a rock fall was observed near Dieppe $1 \mathrm{~W}$. We must bear in mind that these events have return periods 
294 mostly located at the cliff foot or at the cliff top (Fig. 5) and are responsible for the annual
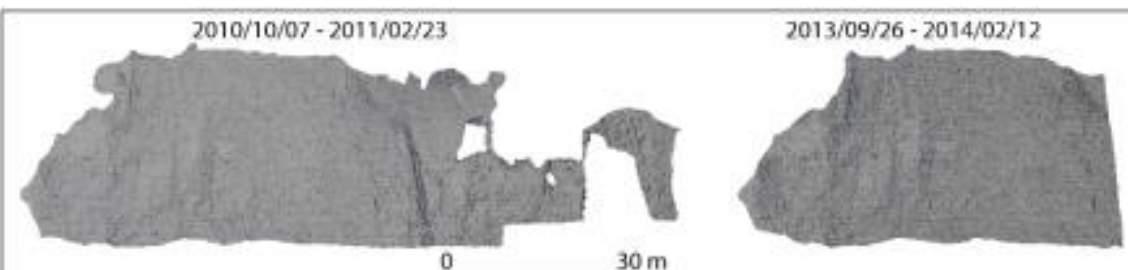

$2014 / 02 / 12-2014 / 07 / 09$
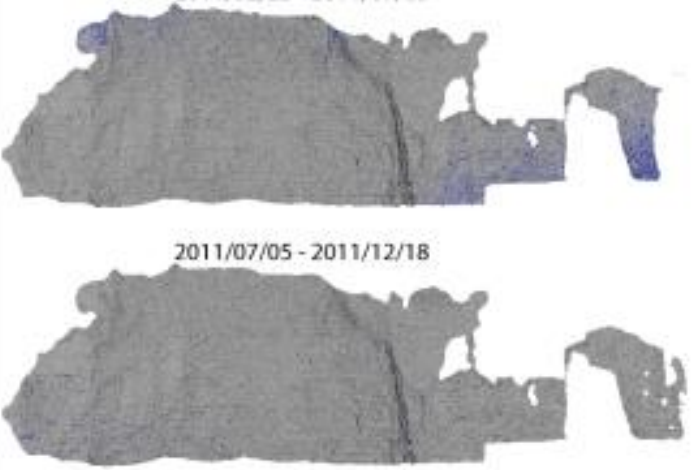

$2011 / 12 / 18-2012 / 03 / 22$

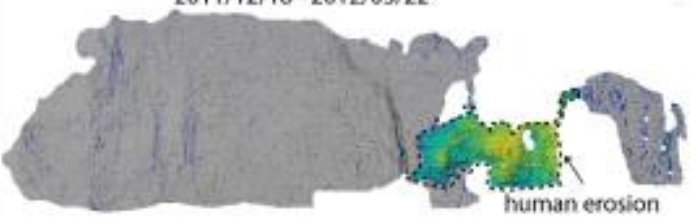

$2012 / 03 / 22-2013 / 02 / 12$

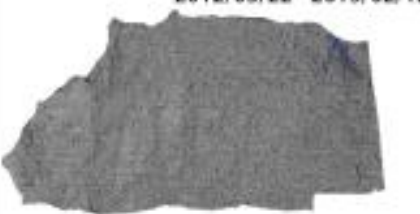

$2013 / 02 / 12-2013 / 09 / 26$
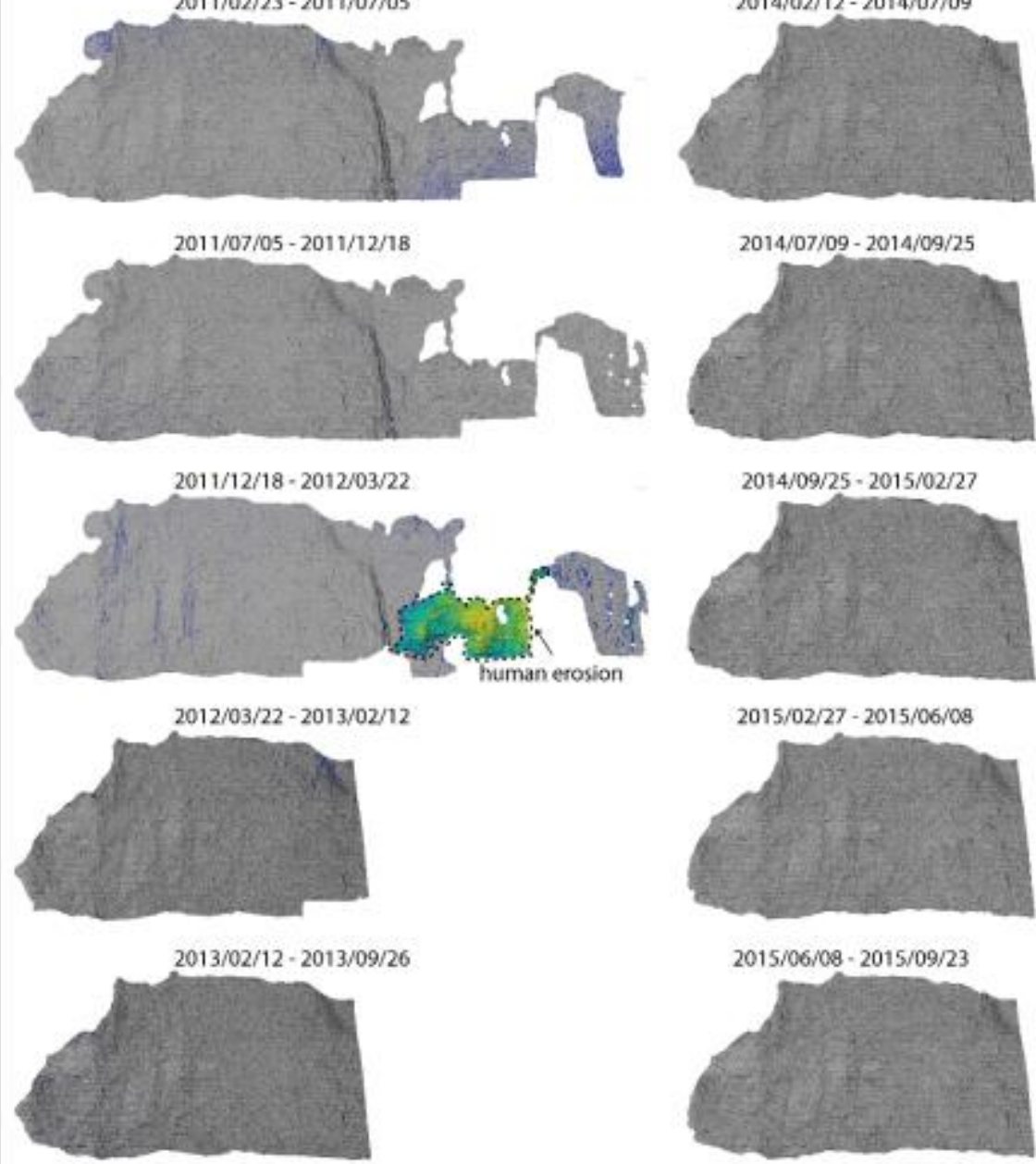

$2014 / 07 / 09-2014 / 09 / 25$

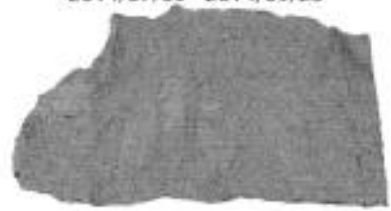

$2014 / 09 / 25-2015 / 02 / 27$

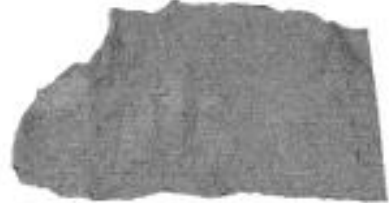

2015/02/27 - 2015/06/08

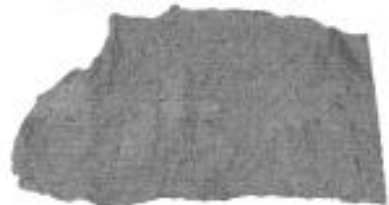

2015/06/08 - 2015/09/23

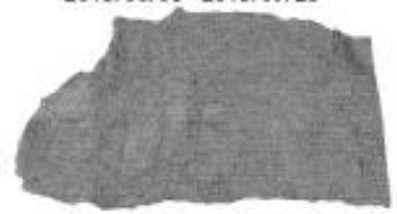

$2015 / 09 / 23-2016 / 01 / 2 B$

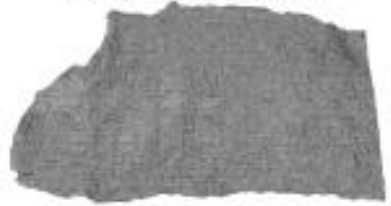

$2016 / 01 / 28-2016 / 06 / 21$

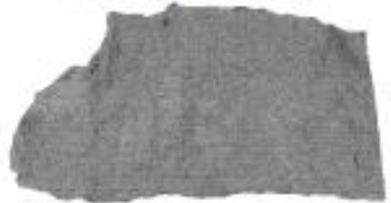

$2016 / 06 / 21-2016 / 10 / 27$

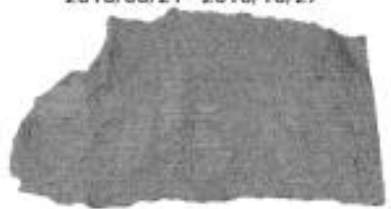

$2016 / 10 / 27 \cdot 2017 / 01 / 25$

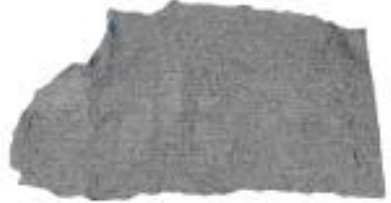

$2017 / 01 / 25-2017 / 06 / 26$

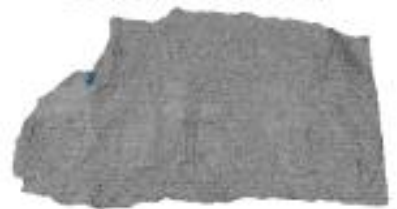

$2017 / 06 / 26-2017 / 11 / 02$

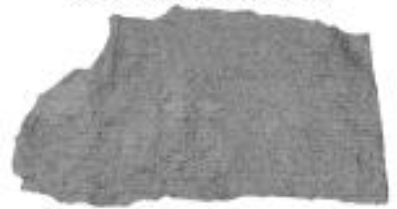

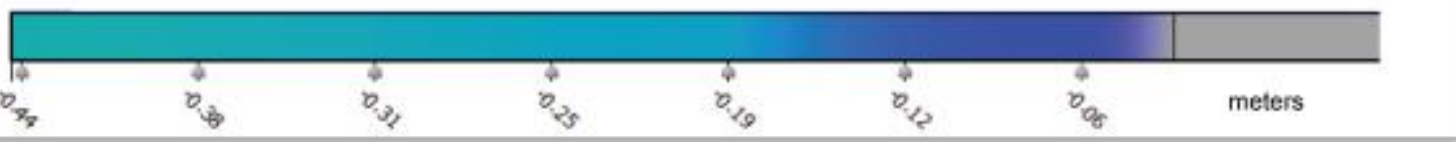

298 Fig. 5: DoDs of the cliff face in Dieppe $2 \mathrm{~N}$ between 2010/10/07 and 2017/11/02. For

299 interpretation of the references to color in this figure, the reader is referred to the web version of this article. 
302 The active cliff in Varengeville-sur-Mer is affected by debris falls (Fig. 6, dark blue) and rock 303 falls (Fig. 6, from light blue to dark red). The location of debris falls are variable: they are 304 located at the cliff foot (DoD 1, 4), at the cliff top (DoD 5, 10), and mainly on the whole cliff 305 face (DoD 2, 11, 14, 15, 16, 18, 19, 20).

306 


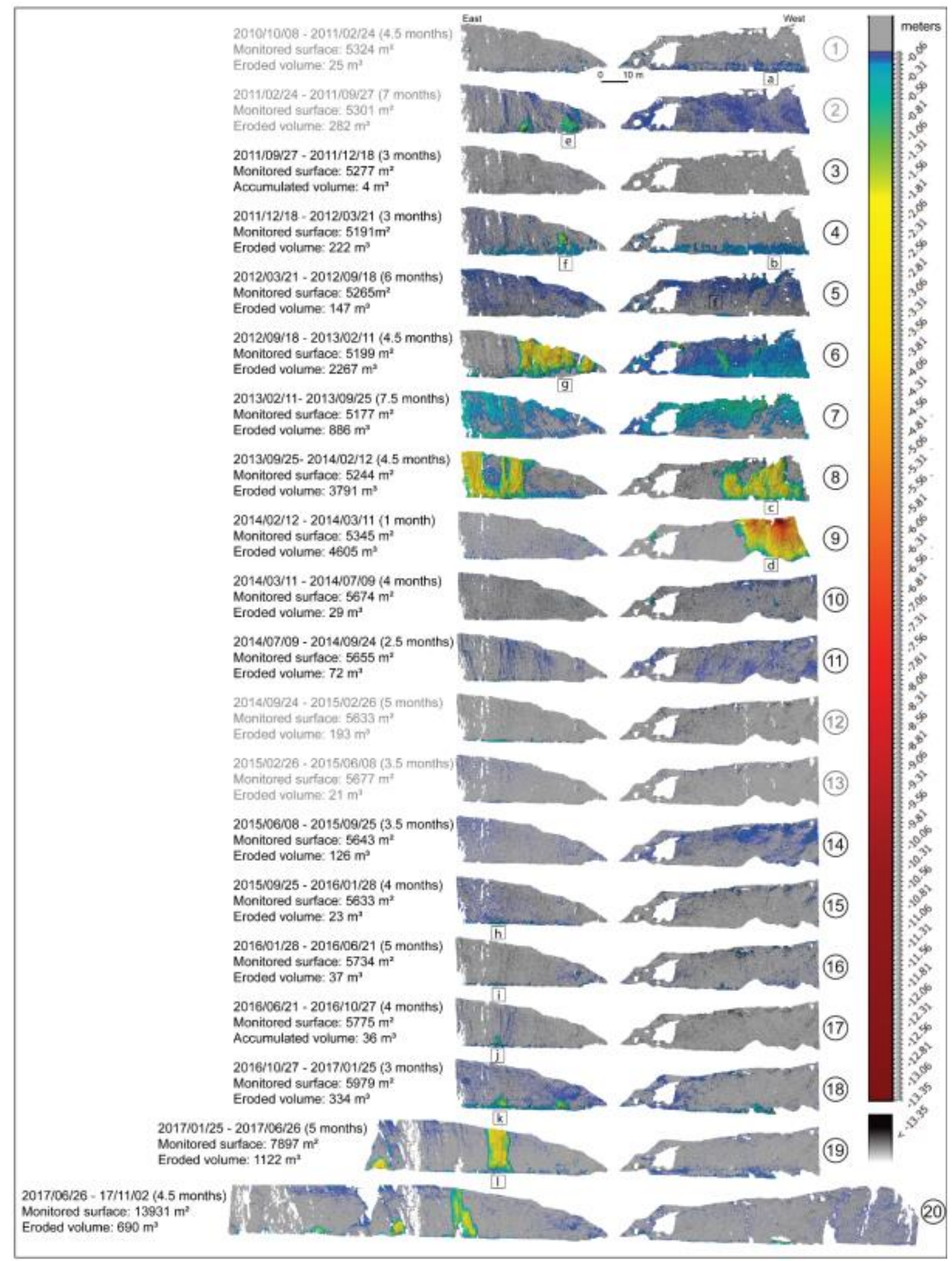

Fig. 6: DoDs of the cliff face in Varengeville-sur-Mer between 2010/10/08 and 2017/11/02 (gray

title and number when the DoD is affected by a high error margin). For interpretation of the references to color in this figure, the reader is referred to the web version of this article. 
312 In order to compare both environments (abandoned and active cliffs), we observe debris falls

313 which are present in both contexts. In the context of the active cliff, debris falls are

314 responsible for less than $2 \%$ of the total erosion $\left(218 \mathrm{~m}^{3}\right)$ measured over the period with

315 retreat rates of $0.00-0.01 \mathrm{~m} /$ year (over $0.36 \mathrm{~m} /$ year). These retreat rates are consistent with

316 the erosion observed on the abandoned cliffs where only debris falls are observed (Fig. 7).

317 This value of $2 \%$ is lower than those evoked in the literature (from $10 \%$ (May and Heeps,

318 1985; Hénaff et al., 2002) to $25 \%$ (Letortu et al., 2015b)). This could be due to different

319 monitoring time periods and the higher error margin of the previous methods of quantification

320 (extrapolation from several debris falls observed in the field). 


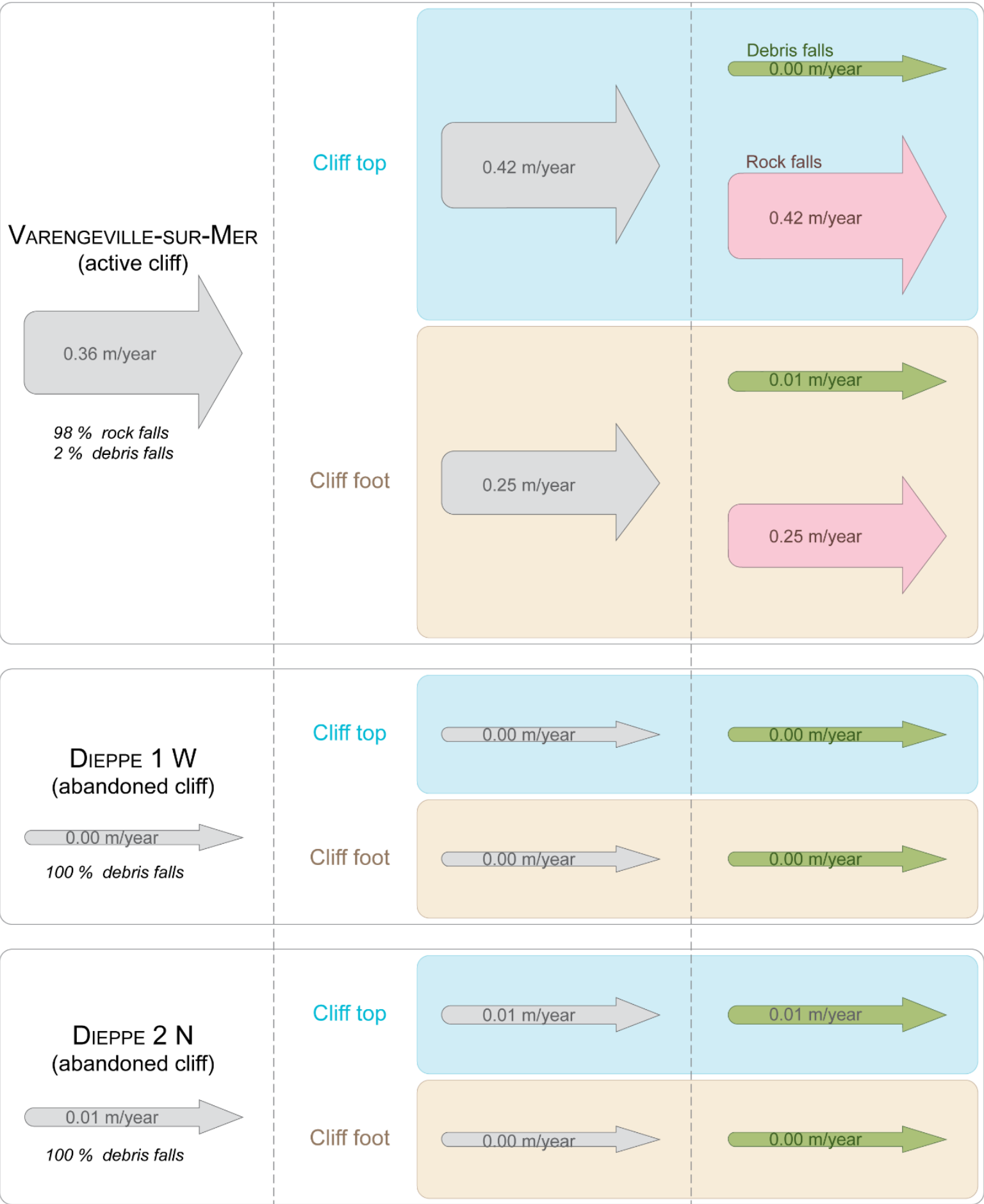

323 Fig. 7: Annual retreat rates in function of location (site and departure area) and type of movements (debris and rock falls). 
326 Because debris falls occur mainly at the cliff top of the abandoned cliff of Dieppe $2 \mathrm{~N}$, the

327 retreat rate by debris falls observed on the active cliff top could be due to the same forcing.

328 The retreat rate appears negligible in Varengeville-sur-Mer (0.00 m/year), so subaerial

329 forcing is probably low for the erosion by debris falls but they may participate in the erosion

330 by rock falls.

\subsection{Profile analysis}

333 Applying the classification scheme of Emery and Kuhn (1982) to the investigated cliff sections, the abandoned cliffs present homogeneous profiles underlining the homogeneity of the rock (Coniacian chalk) (Fig. 8). The profiles are also steady and subvertical $\left(80-85^{\circ}\right)$ underlining the low aggressiveness of subaerial processes on these cliff faces. Indeed, the expected slope value for a continentalized profile is from 5 to $30^{\circ}$ in temperate climates (Pinot, 1998) but the continentalization of between 30 to more than 120 years is short in

339 terms of geomorphological time scales.

340 For the active cliff in Varengeville-sur-Mer (Santonian chalk), changes in the shape of the profiles are observed. These various spatial patterns may highlight differences in the spatial and temporal variability of marine and subaerial processes (Fig. 8). 


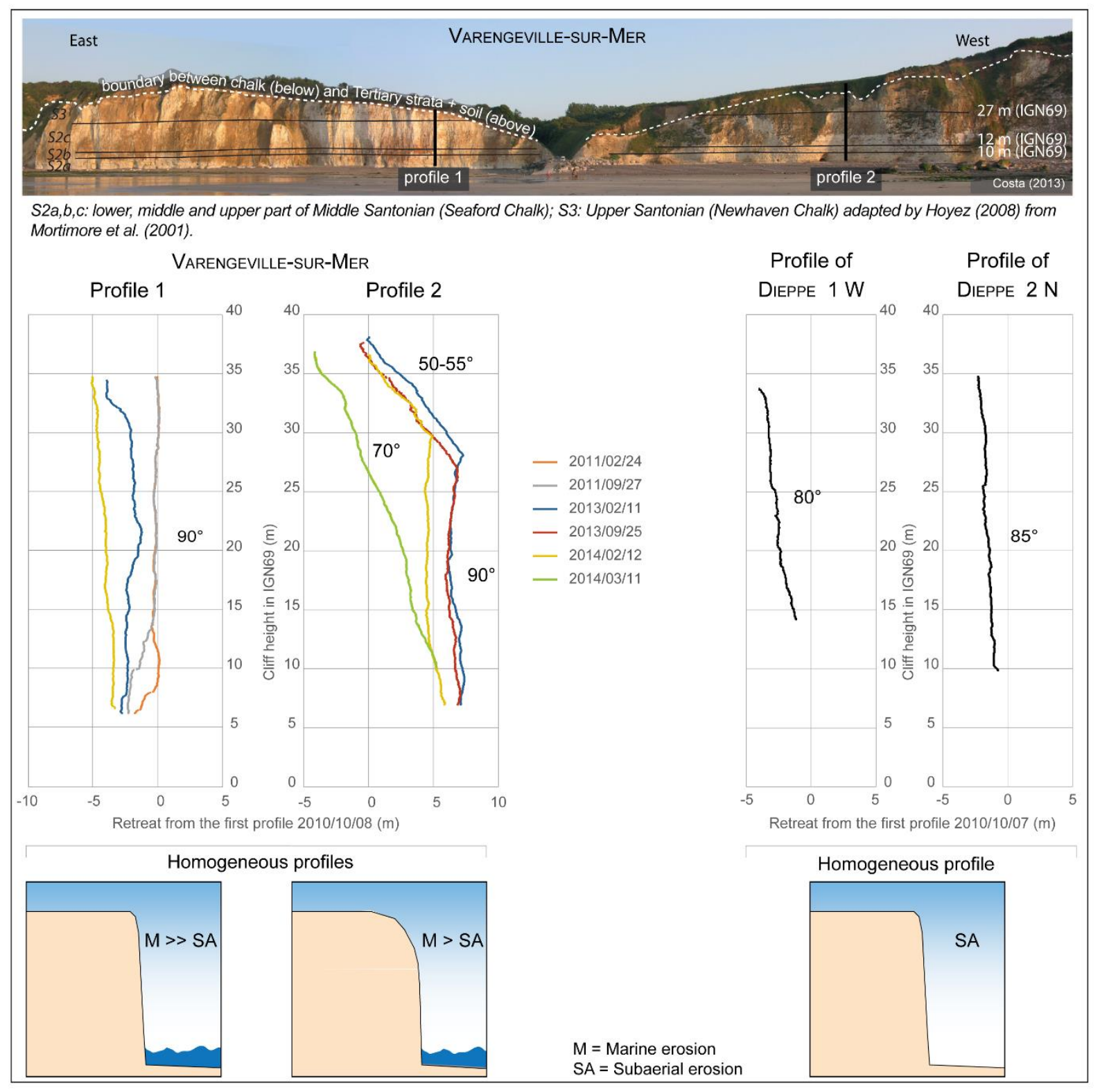

Fig. 8: Main evolutions of the cliff profile in Varengeville-sur-Mer and Dieppe during 7 years of monitoring. For interpretation of the references to color in this figure, the reader is referred to the web version of this article.

349 On the eastern cliff face, profile 1 highlights the lithological homogeneity and the dominant role of marine processes in erosion (Fig. 8):

- between 2011/02/24 and 2011/09/27: attack on the cliff foot probably due to marine processes generating a notch (up to $2.28 \mathrm{~m}$ deep) and an overhang on the upper part (110 $)$; 
- between 2012/09/18 and 2013/02/11: attack on the overhang (there is very little change at the foot) generating a subvertical profile;

- between $2013 / 09 / 25$ and 2014/02/12: attack on the whole cliff face by a vertical failure type generating a vertical profile.

On the western cliff face, profile 2 highlights an erosion difference between the cliff foot and top which seems to be due to the combination of marine and subaerial agents and processes in the evolution of the profile (Fig. 8):

- between $2013 / 02 / 11$ and $2013 / 09 / 25$ : attack on the cliff top by subaerial processes (erosion up to $0.62 \mathrm{~m}$ ) whereas the cliff foot seems less affected by marine processes (erosion up to $0.21 \mathrm{~m}$ );

- between $2013 / 09 / 25$ and 2014/02/12: attack on the cliff foot probably due to marine processes (erosion up to $1.49 \mathrm{~m}$ ) and a rock fall of the whole cliff face (vertical failure type) maintaining a vertical profile (erosion up to $2.08 \mathrm{~m}$ );

- between 2014/02/12 and 2014/03/11: attack at the top of the cliff due to subaerial forcing (erosion up to $5.82 \mathrm{~m}$ ) generating a homogeneous profile but with a slope of $70^{\circ}$.

During the 7 years of monitoring, marine processes seem largely dominant in the active cliff context with regard to vertical profiles, because the latter are maintained by the undermining and removal role of marine agents. However, subaerial processes also contribute to the retreat.

Our erosion results have been linked to external factors to be more precise about the dominant forcing. Two "dead times" and two "high points" of erosion can be identified and have been linked to environmental conditions (Fig. 9):

- October 2010 to September 2012: A low erosion period occurred with a maximum retreat of $2.31 \mathrm{~m}$ and an average annual retreat rate of $0.07 \mathrm{~m} / \mathrm{year}$. This period of $23.5 \mathrm{months}$ is characterized by calm wave conditions, a cold and humid fall in 2010 (17 daily freeze/thaw cycles in December), a mild and dry winter and spring in 2011, a wet summer in 2011 (+141\% rainfall in August in comparison with the 1971-2000 climate 
normal from Météo-France data), a mild and dry fall in 2011 and the winter of 2012, and a humid spring-summer in 2012.

- September 2012 to March 2014: A high erosion period (maximum retreat of $12.93 \mathrm{~m}$ and an average annual retreat rate of $1.51 \mathrm{~m} /$ year) occurred for 17.5 months and was characterized by high rainfall in October and December 2012, and with a cold winter (24 daily freeze/thaw cycles); the spring of 2013 had a dry April and June (-62\% and $-67 \%$ rainfall in comparison with the climate normal, respectively) but summer months of July and August were warm and rainy $(+23 \%$ rainfall in July with thunderstorms, $+110 \%$ in August), the fall and winter of 2013-2014 were particularly mild (an average of $+70 \%$ of mean temperature for the three winter months) but characterized by violent storms and rainfall (+76\% in November) and with frequent storm wave conditions.

- March 2014 to January 2017: A low erosion period (maximum retreat of $2.73 \mathrm{~m}$ and an average annual retreat rate of $0.02 \mathrm{~m} /$ year) occurred for 31.5 months. This period is characterized by a drier and warmer spring in 2014 than the climate normal, a very rainy summer $(+73 \%$ and $+251 \%$ in July and August, respectively), a dry fall (-83\% in September, $-45 \%$ in October and $-42 \%$ in November) but with storm wave conditions in October, a mild and rainy winter in 2014-2015 (+55 \% rainfall in January 2015), a dry spring in 2015 (-55 \% rainfall in April), and a warm summer in 2015 characterized by a very rainy July and August (+126\% rainfall in August); the fall and winter of 2015-2016 were mild $(+72 \%$ of mean temperature in November and $147 \%$ in December, $177 \%$ in January) and with storm wave conditions in October but the winter was rainy (+84 \% in January, $+108 \%$ in February), the spring of 2016 was "classic", summer 2016 was warm $(+15 \%$ of mean temperature for the three summer months) and almost dry $(-85 \%$ in July 2016), followed by a "classic" October and November but a very dry December (-85 $\%$ rainfall).

- January to November 2017: A high erosion period (maximum retreat of $6.21 \mathrm{~m}$ and an average annual retreat rate of $0.28 \mathrm{~m} /$ year) occurred with a mild (except January with 14 freeze/thaw cycles), calm and dry winter (-15\% and $-36 \%$ rainfall in January and March 

$;+40 \%$ of mean temperature in February and March), the spring and summer of 2017 were quite warm and dry ( $-51 \%$ rainfall and $+25 \%$ of mean temperature in June, $-34 \%$ in July but $+71 \%$ in August) but the month of September had storm wave conditions and the fall had warmer temperatures than the climate normal $(+37 \%$ of mean temperature in October) and had variable rainfall (-47\% in October, $+37 \%$ in November).

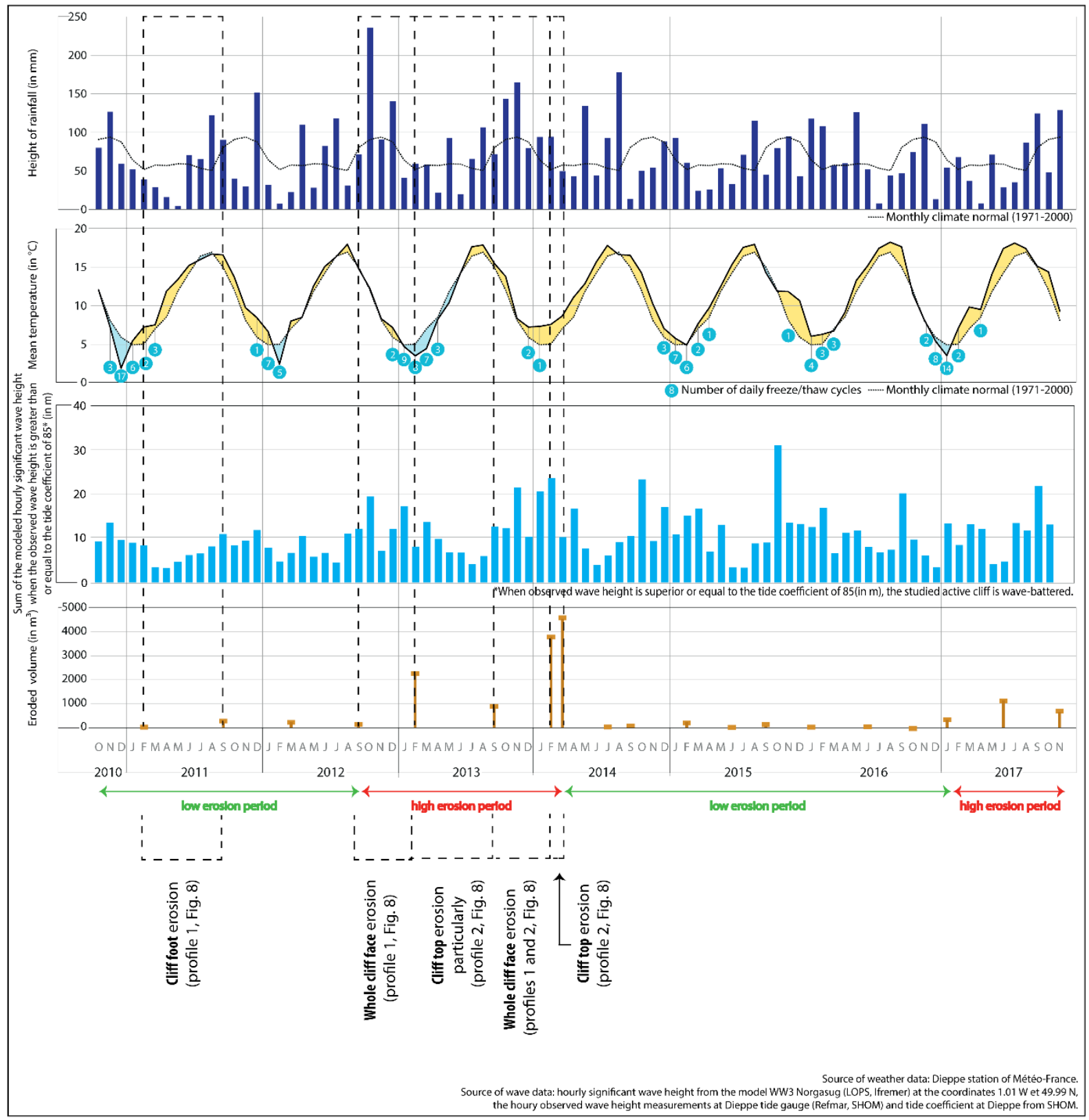

Fig. 9: Evolution of climate (rainfall, temperature, number of freeze/thaw cycles from Météo-

417 France data) and wave conditions (sum of the modeled hourly significant wave height (in $\mathrm{m}$ ) when the hourly observed wave height is greater than or equal to the tide coefficient of 85) 
around Dieppe (from WW3 Norgasug data (LOPS, IFREMER), and SHOM data) and the erosion in Varengeville-sur-Mer.

As per Letortu et al. (2015a), the whole cliff face erosion occurs particularly during high rainfall and high wave conditions over the 7-year monitoring period. However, the relationships are not systematic as in August and October 2014 when high rainfall and high wave conditions occurred respectively without significant erosion (Fig. 9). Due to the imprecise dating of falls (time frequency of 4-5 months), it is not possible to be more explicit about the main processes responsible for erosion. Moreover the determination has four main sources of difficulty:

- $\quad$ First, the non-linear evolution of the coastal environment limits direct cause and effect relationships. Thresholds, hysteresis, synergies/combinations, positive and negative feedbacks, and 'purge' effect (described in detail in Viles, 2012) all complicate the analysis of relationships. For example, the relative role of marine and subaerial processes in cliff erosion may change over time, because platforms gradually widen over long time periods, which affects the amount of wave energy delivered to the foot of the cliff (negative feedback);

- Secondly, the boundary conditions (sea level, climate, geology, tide and wind wave) modulate the domination of agents and processes over the evolution of the coast at a given place and time, requiring spatial and temporal scales to be jointed together. For example, the erosive power of the ocean will depend on the relative balance between tidal and wave climates (Kennedy et al., 2014b);

- Third, the cliff is also inherited past environmental changes (Trenhaile, 2002): in our understanding of current processes and their impacts, we must also integrate long-term rock degradation (Griggs and Trenhaile, 1994; Swenson et al., 2006; Joyal et al., 2016);

- Finally, studies often focus on the cliff face while the cliff belongs to a vast system including nearshore, platform, cliff and hinterland (Trenhaile, 1987). Studies that focus 
on a single component are likely to provide only a partial view of the behavior of the entire slope (Lim, 2014).

4.4. Basal notch creating instability on the whole cliff face

450

451

452

453

Figs. 6 and 8 show one of the retreat modalities previously described along the SeineMaritime coastline (Costa et al., 2006a; Dewez et al., 2013; Letortu et al., 2015b): the creation of a basal notch (created by debris falls or rock falls) that, by overhanging, will gradually destabilize the whole cliff face and generate a rock fall from the whole cliff face. Three cases are observed during the seven years of monitoring on both sides in Varengeville-sur-Mer (Fig. 6, on the western part: a to $d$; on the eastern one: e to $g$, and $h$ to I). For example, debris fall 'a' generates a maximal basal notch on the western side of $0.2 \mathrm{~m}$, reactivated by debris fall 'b' (maximal notch of $0.25 \mathrm{~m}$ ). A few months later, the created overhang is eroded by rock fall ' $c$ ' from the whole cliff face $\left(1875 \mathrm{~m}^{3}\right)$ which is reactivated a month later by rock fall 'd' $\left(4616 \mathrm{~m}^{3}\right)$.

\section{Discussion}

\subsection{Profile analysis}

The profile analysis as a proxy of the power balance between the resistance and homogeneity of the material outcropping on the cliff face and the combined aggressiveness of marine and/or subaerial forcing has several limitations. First, the profile evolution is often the result of multiple factors which interact in time and space which can make the definite interpretation of the responsible factor more complex. Second, the analysis can be complicated by local effects (as in profiles 1 and 2 in Varengeville). Third, "equifinality" can occur: the same profile can be obtained by different processes.

\subsection{Roles of structural variations and of the gravel barrier}

The Dieppe cliff profiles (1 W and $2 \mathrm{~N}$ ) and profile 1 in Varengeville-sur-Mer are similar in their subverticality and their homogeneity. This highlights (1) the low efficacy of subaerial 
forcing (or, for the active cliff, the very high efficacy of marine forcing) in cliff erosion, and (2) a close resistance between Santonian and Coniacian chalk stages with a common mode of failure: the vertical failure mode.

But at the Varengeville site, profiles 1 and 2 are different (Fig. 8). Marine forcing is predominant but the role of subaerial processes is much more visible in profile 2 with a more convex cliff top (softer slope). A hypothesis could be the greater thickness of the overlying Tertiary strata on the western part, which, due to the presence of perched groundwater (Bignot, 1971), would accelerate the retreat at the top of the cliff. However, cliff face retreat rates were calculated for each side of the dry valley: annual retreat rates are almost the same with $0.37 \mathrm{~m} /$ year for the western part and $0.35 \mathrm{~m} /$ year for the eastern part. Difference in thickness of Tertiary strata does not seem to influence retreat rates but it can influence the modality of retreat. Another hypothesis could be a difference in fracturing between the two sides of the dry valley, modifying drainage and infiltration. A more detailed analysis of the fracturing needs to be carried out. The last hypothesis could be the influence of the descending road to the sea which, acting as a groin, accumulates gravel on the front western part (up to $5 \mathrm{~m}$ thick) to the detriment of the immediate downdrift side (eastern part, up to 2.5 $\mathrm{m}$ thick). The gravel barrier could cause negative feedback with increased wave protection at the cliff foot, leading to a likely decrease in the efficacy of marine processes on the western part of the cliff foot. In addition, profile 2 has no basal notch although this is the case on profile 1, highlighting the role of marine forcing on the eastern part. However, the amount and configuration of beach material can also create positive feedback with higher wave erosive efficacy by providing abrasive elements (Sunamura, 1992), as evoked in our previous paper in the study area (Letortu et al., 2015b) (Fig. 6, DoDs 1 and 4).

\subsection{Subaerial forcing inferior to marine forcing but non-negligible}

The subvertical profiles of the active cliff and the current annual retreat rate, 36 times higher when the cliff is wave-battered, highlight the supremacy of marine over subaerial controls in the erosion of chalk cliffs around Varengeville-sur-Mer between 2010 and 2017. However, 
subaerial processes are present (the freeze/thaw action is visible in DoD 19 in Fig. 6 and is supported by Fig. 10, the runoff zones are visible at the cliff top in Figs. 5, 6), but they seem much less active than marine processes in destabilizing cliffs.
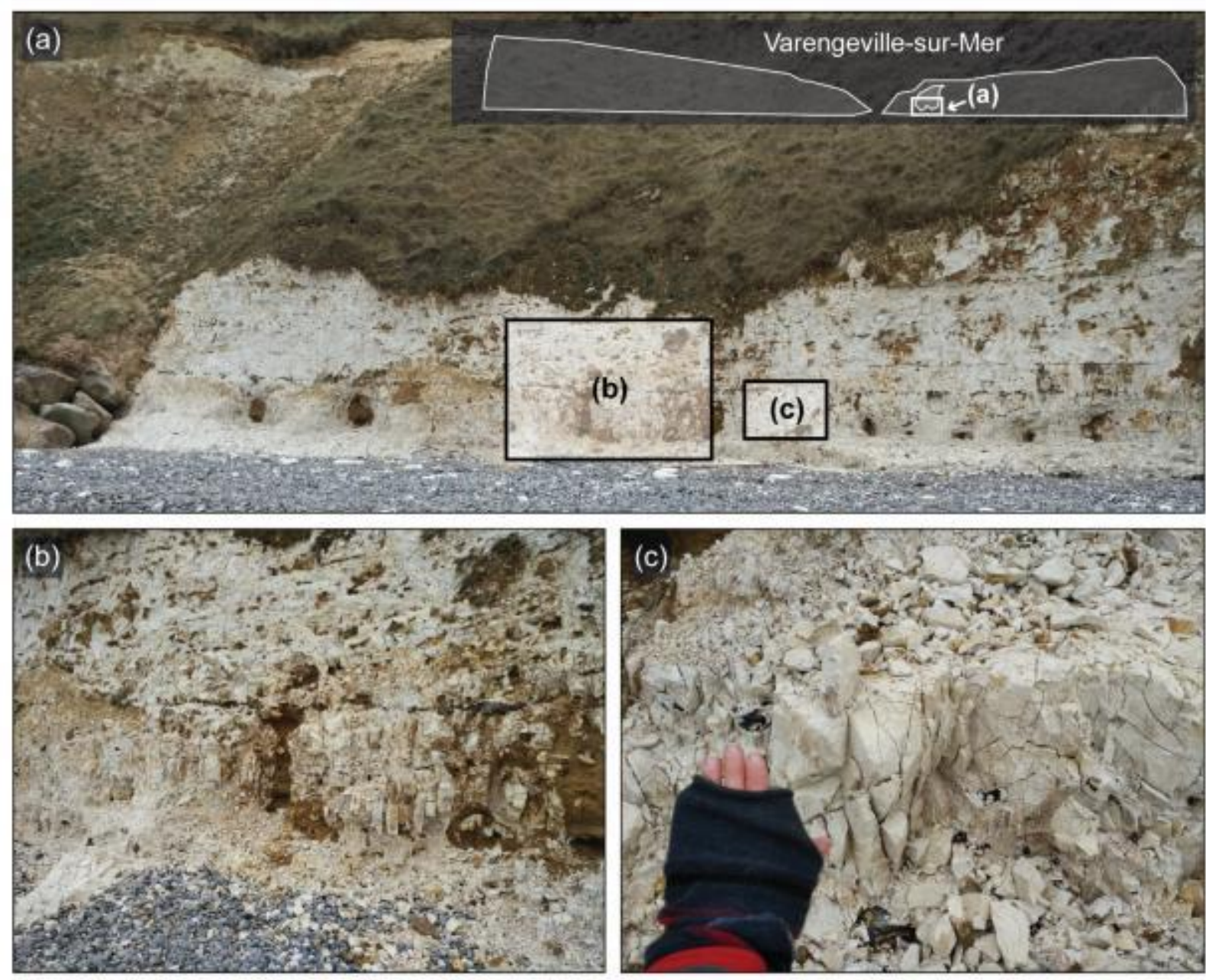

Fig. 10: Successive zooms of debris falls at the cliff foot of Varengeville-sur-Mer after freeze/thaw cycles $(2017 / 01 / 25)$

The slow continentalization of the abandoned cliffs in Dieppe may be explained by the low efficacy of subaerial processes in erosion but it is important to note that these morphological adjustments take time, and, local factors, notably hydrogeomorphological, could explain this slow evolution. The plateau here is characterized by a high fracturing of the chalky block (close to the Bray fault) where a karstic system may extend along pre-existing fracturing. 
Dieppe $1 \mathrm{~W}$ and $2 \mathrm{~N}$ have a well-developed karstic network that was widened during the

Second World War, before being roughly filled. Moreover, the plateau is also locally characterized by a slope and a dip towards the hinterland, lowering the chalk water table level at the foot of the cliff, and directing a large part of the surface flows towards the dry valley a few hundred meters behind the cliff (stereogram of Dieppe $2 \mathrm{~N}$; Fig. $2 \mathrm{~d}$ ). The monitored chalk cliffs could be less saturated than elsewhere due to these local factors.

The combined marine and subaerial processes alternate in time and space in the active cliff context. TLS monitoring has made it possible to visualize "erosion patterns" in Varengevillesur-Mer which appear to be seasonal: between September and February, the cliff foot is often eroded partly by marine processes while between March and September, it is rather the cliff top that is eroded due to subaerial activity (Fig. 6). Moreover, erosion increased in Varengeville-sur-Mer during the winter of 2013-2014, when conditions were particularly stormy on the Atlantic and Channel coasts (Blaise et al., 2015; Earlie et al., 2015) (Fig. 9). Our results confirm that marine processes play the most important erosive role during the studied period, and also that of removing falls at the foot of the cliffs. Indeed, the roles of marine processes are visible following stormy periods with 1) the cliff foot bleached due to wave erosive action and 2) a milky sea due to the dissolution of chalk falls (Fig. 11).

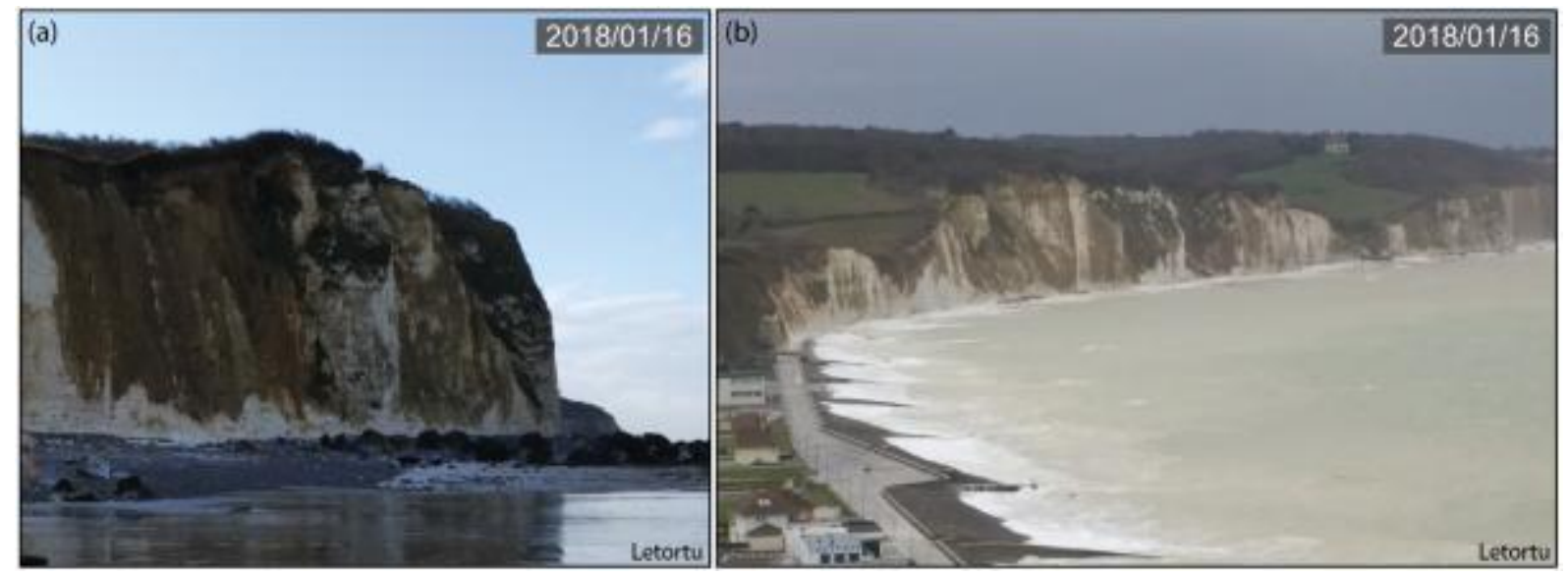

Fig. 11: Marine action visible after a stormy period (December 2017-January 2018) in Varengeville-sur-Mer (a) with bleached cliff foot (b) and the removal of falls by dissolution into the sea. 
538 The removal role can be estimated from the rock fall of 2014/02/15-16 observed on the

539 western cliff face at Varengeville-sur-Mer and evacuated between 2016/10/28 and

$5402017 / 01 / 25$ (Fig. 6). The minimum monthly removal rate is $53 \mathrm{~m}^{3}$ per month. This removal

541 rate seems low compared to the literature and our field observations beyond the studied

542 sites. Hénaff et al. (2002) report removal volumes of around $40 \mathrm{~m}^{3} / \mathrm{day}$, or $14500 \mathrm{~m}^{3} /$ year. In

543 Varengeville-sur-Mer, $2 \mathrm{~km}$ west of the area monitored by TLS, a rock fall of $5700 \mathrm{~m}^{3}$

544 occurred at the end of May 2006 and disappeared six months later, in December 2006. The

545 removal rate is close to that found by Hénaff et al. with an evacuated volume of $30 \mathrm{~m}^{3} /$ day for

546 this rock fall (Fig. 12).

547
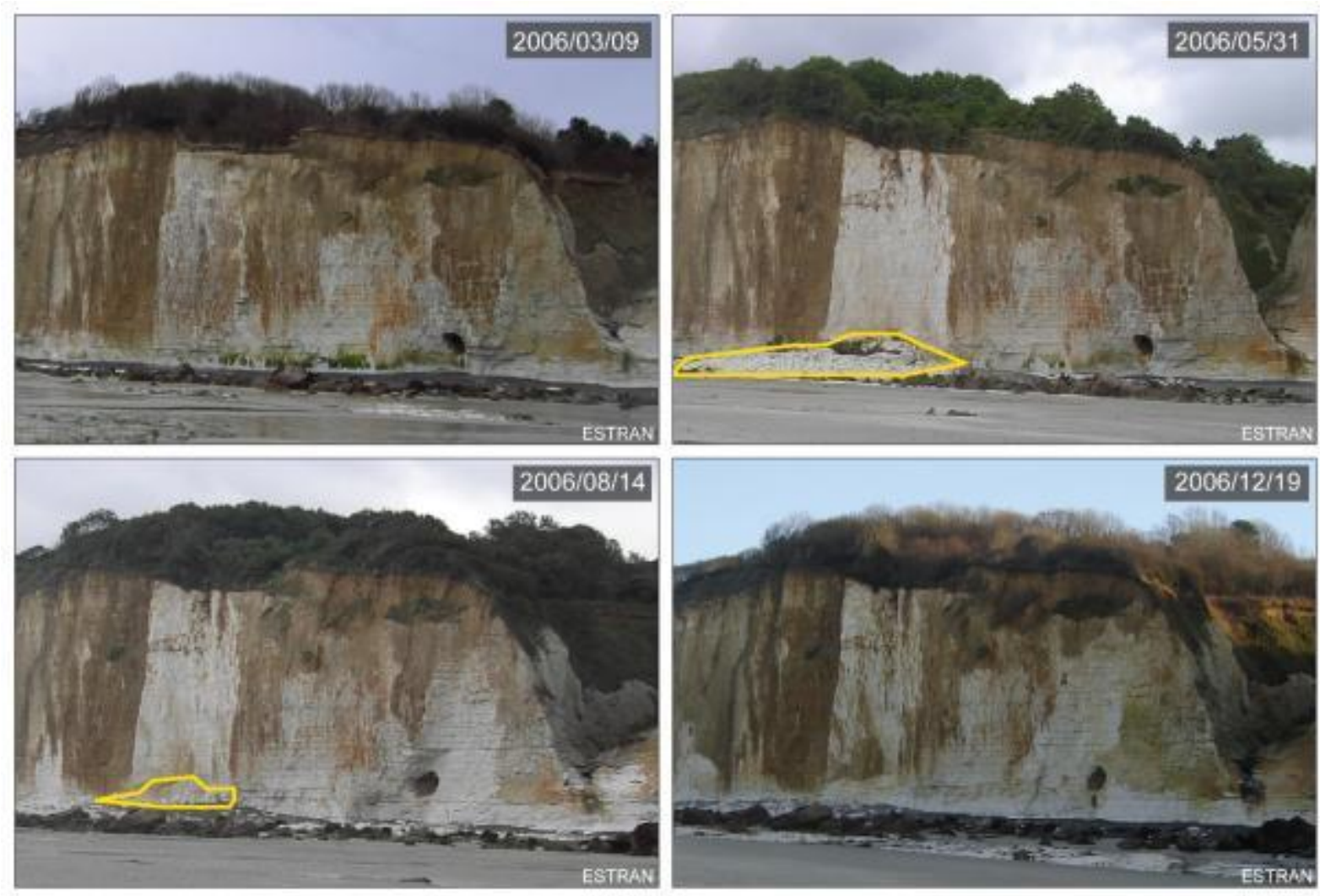

Fig. 12: Evolution of the cliff face in Varengeville-sur-Mer (2 km from the monitored site) between 2006/03/09 and 2006/12/19 with a rock fall of $5700 \mathrm{~m}^{3}$ in late May. In August, the rock fall is partially removed, and by December 2006 it has been completely removed. 
Thus, a high spatial variability of removal rates is observed. Beyond the elapsed time interval between the two surveys, the removal rate is explained by a multitude of factors which influence the modalities and the efficacy of the removal (size of blocks and chalk types, kinematics of rock falls, volume of rock falls depending on the height of the cliffs and the fracturing of the chalk, volume of gravel barrier etc.).

\section{Conclusions}

Erosion of three chalk cliff faces in Normandy was monitored every 4-5 months since October 2010 using a terrestrial laser scanner. These cliff faces with close structural characteristics (including lithology with Upper Cretaceous chalk with flint bands of Coniacian and Santonian ages) are exposed differently to marine processes: the active Varengevillesur-Mer cliff, affected by marine and subaerial processes, and the two abandoned Dieppe cliffs evolving under the action of subaerial processes only. The choice of sites and the high frequency, high resolution and centimeter precision monitoring ( \pm 0.02 to $0.03 \mathrm{~m}$ ) make it possible to improve the understanding of 1) the cliff face retreat rates, 2) the modalities of cliff evolution, and 3) the efficacy of marine and subaerial controls in erosion of the studied cliff faces.

Over the 85 months between October 2010 and November 2017, our results highlight the predominance of marine processes in the retreat of the coastal chalk cliffs because: 1) the current annual retreat rate is 36 times higher in the active cliff context than in the abandoned cliff context; 2) the cliff profiles are subvertical due to the primacy of marine processes in the active cliff context and the low effectiveness of subaerial processes in the abandoned cliff context; and 3) the location of erosion highlights the great effectiveness of marine processes in destabilizing cliffs (from the generation of a basal notch through the overhang generating instability to the triggering of a rock fall of the whole cliff face) and in the removal of falls. These results indicate that TLS data can be very useful in monitoring coastal cliff erosion and in contributing to the debate on the primacy of agents and processes responsible for erosion and the triggering of falls. Research perspectives using our database are numerous, 
581 including the implementation of "rock fall" hazard warning systems. The various studies

582 conducted in continental (Abellán et al., 2010; Royán et al., 2014; Kromer et al., 2017) and

583 coastal areas (Rosser et al., 2007) focus on two types of precursory signs: the activity of falls

584 before failure and deformations before failure. One of the important issues in forecasting

585 systems lies in the coupling of spatial and temporal predictions, which are still rare in the

586 scientific literature (e.g. Rosser et al., 2007; Arosio et al., 2009; Kromer et al., 2017) because

587 of their great complexity (Abellán et al., 2014).

588 The current TLS monitoring must continue to improve temporal representativeness. Only

589 reliable, homogeneous and sustainable monitoring will allow a better understanding of cliff

590 evolution. The annual retreat rates will be refined in Dieppe by extending the monitoring time,

591 which will allow the margin of error to be expanded. An increase in the temporal sampling of

592 measurements would be desirable to refine knowledge on the contribution of marine and

593 subaerial agents and processes responsible for triggering falls in Varengeville-sur-Mer. A

594 high temporal sampling would also make it possible to develop the research axis on the

595 precursory signs of failure. The great diversity of current monitoring instruments makes it

596 possible to be more reactive (Letortu et al., 2018).

597 One of the limitations of our results is that they are difficult to transpose, as they are very

598 dependent on the three studied sites. Other methods such as the mobile laser scanning

599 (Michoud et al., 2014), make it possible to cover larger areas but their implementation costs

600 and the necessary technical know-how are obstacles to their deployment. The spatial

601 representativeness of the TLS monitoring we conducted has been widened in order to extend

602 the scope of our results in various contexts. Since November 2017, TLS monitoring of the

603 Sainte-Marguerite-sur-Mer cliff (6 km west from the TLS site in Varengeville-sur-Mer) has

604 begun and it will be linked to a continuous cliff face multiparameter monitoring (temperatures, 605 water table level, seismicity, rainfall, sea water level etc.) during the winter 2018-2019.

606

607

\section{Acknowledgements}


608

609

610

611

612

613

614

617

618

619

620

621

622

623

624

625

626

627

This work is part of the Service National d'Observation DYNALIT, via the research infrastructure ILICO. This work was supported by the French "Agence Nationale de la Recherche" through the "Laboratoire d'Excellence" LabexMER [ANR-10-LABX-19-01] program, and co-funded by a grant from the French government through the "Investissements d'Avenir" and the Brittany Region. This work was also supported by the ANR project "RICOCHET: multi-risk assessment on coastal territory in a global change context" funded by the French Research National Agency [ANR-16-CE03-0008].

The authors are grateful for the constructive criticisms and comments of referees which have improved the manuscript.

\section{References}

Abellán, A., Calvet, J., Vilaplana, J.M., Blanchard, J., 2010. Detection and spatial prediction of rockfalls by means of terrestrial laser scanner monitoring. Geomorphology $119,162-171$. https://doi.org/10.1016/j.geomorph.2010.03.016

Abellán, A., Oppikofer, T., Jaboyedoff, M., Rosser, N.J., Lim, M., Lato, M.J., 2014. Terrestrial laser scanning of rock slope instabilities. Earth Surf. Process. Landf. 39, 80-97.

https://doi.org/10.1002/esp.3493

Arosio, D., Longoni, L., Papini, M., Scaioni, M., Zanzi, L., Alba, M., 2009. Towards rockfall forecasting through observing deformations and listening to microseismic emissions. Nat. Hazards Earth Syst. Sci. 9, 1119-1131. https://doi.org/10.5194/nhess-9-1119-2009 Auffret, J.P., Bignot, G., 1978. Dieppe (est). Carte géologique à 1/50000.

Augris, C., 2004. Evolution morpho-sédimentaire du domaine littoral et marin de la SeineMaritime. Ifremer.

Bernatchez, P., Dubois, J.M., 2008. Seasonal quantification of coastal processes and cliff erosion on fine sediment shorelines in a cold temperate climate, north shore of the St. Lawrence maritime estuary, Québec. J. Coast. Res. 24, 169-180. https://doi.org/10.2112/040419.1 
Bernatchez, P., Jolivet, Y., Corriveau, M., 2011. Development of an automated method for continuous detection and quantification of cliff erosion events. Earth Surf. Process. Landf. 36, 347-362. https://doi.org/10.1002/esp.2045

Bezore, R., Kennedy, D.M., lerodiaconou, D., 2016. The drowned Apostles: the longevity of Sea stacks over Eustatic cycles. J. Coast. Res. 75, 592-596. https://doi.org/10.2112/SI75119.1

Bignot, G., 1971. Dieppe (ouest). Carte géologique à 1/50000.

Bignot, G., 1962. Etude sédimentologique et micropaléontologique de l’Eocène du Cap d'Ailly (près de Dieppe-Seine-Maritime). Paris.

Blaise, E., Suanez, S., Stéphan, P., Fichaut, B., David, L., Cuq, V., Autret, R., Houron, J., Rouan, M., Floc'h, F., Ardhuin, F., Cancouët, R., Davidson, R., Costa, S., Delacourt, C., 2015. Bilan des tempêtes de l'hiver 2013-2014 sur la dynamique de recul du trait de côte en Bretagne. Géomorphologie Relief Process. Environ. 21, 267-292. https://doi.org/10.4000/geomorphologie.11104

Brooks, S.M., Spencer, T., 2010. Temporal and spatial variations in recession rates and sediment release from soft rock cliffs, Suffolk coast, UK. Geomorphology 124, 26-41. https://doi.org/10.1016/j.geomorph.2010.08.005

Cavelier, C., Lorenz, J., 1987. Aspect et évolution géologiques du Bassin de Paris, Association des Géologues du Bassin de Paris. ed.

Cavelier, C., Mégnien, C., Pomerol, C., Rat, P., 1979. Le Bassin de Paris. Bull. Inf. Géologues Bassin Paris 16, 2-52.

Cazes, M., Torreilles, G., Bois, C., Damotte, B., Galdeano, A., Hirn, A., Mascle, A., Matte, P., Van Ngoc, P., Raoult, J.F., 1985. Structure de la croûte hercynienne du Nord de la France: premiers résultats du profil ECORS. Bull. Société Géologique Fr. 8, 925-641. https://doi.org/https://doi.org/10.2113/gssgfbull.I.6.925

Costa, S., 2005. Falaises à recul rapide et plages de galets: de la quantification des dynamiques d'un système complexe à la caractérisation des risques induits. Habilit. À Dir. Rech. Univ. Bretagne Occident. Brest Tome 1, 330. 
Costa, S., 1997. Dynamique littorale et risques naturels : L'impact des aménagements, des variations du niveau marin et des modifications climatiques entre la baie de Seine et la baie de Somme (Haute-Normandie, Picardie; France). Paris 1.

Costa, S., Delahaye, D., Freiré-Diaz, S., Di Nocera, L., Davidson, R., Plessis, E., 2004.

Quantification of the Normandy and Picardy chalk cliff retreat by photogrammetric analysis. Geol. Soc. Lond. Eng. Geol. Spec. Publ. 20, 139-148.

Costa, S., Lageat, Y., Hénaff, A., 2006a. The gravel beaches of north-west France and their contribution to the dynamic of the coastal cliff-shore platform system. Z. Geomorphol. 144, $199-214$.

Costa, S., Laignel, B., Hauchard, E., Delahaye, D., 2006b. Facteurs de répartition des entonnoirs de dissolution dans les craies du littoral du Nord-Ouest du Bassin de Paris. Z. Geomorphol. 50, 95-116.

Dewez, T.J.B., Girardeau-Montaut, D., Allanic, C., Rohmer, J., 2016. Facets : a

Cloudcompare Plugin to Extract Geological Planes from Unstructured 3d Point Clouds.

ISPRS - Int. Arch. Photogramm. Remote Sens. Spat. Inf. Sci. 41B5, 799-804. https://doi.org/10.5194/isprs-archives-XLI-B5-799-2016

Dewez, T.J.B., Regard, V., Duperret, A., Lasseur, E., 2015. Shore platform lowering due to frost shattering during the 2009 winter at Mesnil Val, English channel coast, NW France. Earth Surf. Process. Landf. 40, 1688-1700.

Dewez, T.J.B., Rohmer, J., Regard, V., Cnudde, C., 2013. Probabilistic coastal cliff collapse hazard from repeated terrestrial laser surveys: Case study from Mesnil Val (Normandy, northern France). J. Coast. Res. 702-707. https://doi.org/10.2112/SI65-119

Dikau, R., Brunsden, D., Schrott, L., Ibsen, M.L., 1996. Landslide Recognition: Identification, Movement and Causes. John Wiley \& Sons, Chichester.

Duperret, A., Genter, A., Martinez, A., Mortimore, R.N., 2004. Coastal chalk cliff instability in NW France: role of lithology, fracture pattern and rainfall, in: Coastal Chalk Cliff Instability, Geological Society Engineering Geology Special Publication. Mortimore R.N. and Duperret A., London, pp. 33-55. 
Duperret, A., Genter, A., Mortimore, R.N., Delacourt, B., De Pomerai, M.R., 2002. Coastal rock cliff erosion by collapse at Puys, France: The role of impervious marl seams within chalk of NW Europe. J. Coast. Res. 18, 52-61.

Earlie, C.S., Young, A.P., Masselink, G., Russell, P.E., 2015. Coastal cliff ground motions and response to extreme storm waves. Geophys. Res. Lett. 42, 847-854. https://doi.org/10.1002/2014GL062534

Emery, K.O., Kuhn, G.G., 1982. Sea cliffs: their processes, profiles, and classification. Geol. Soc. Am. Bull. 93, 644-654.

Evrard, H., Sinelle, C., 1987. La stabilité des falaises du Pays de Caux (Normandie), in: Actes Du Colloque "Mer et Littoral. Couple à Risque", La Documentation Française, Paris. pp. 84-91.

Genter, A., Duperret, A., Martinez, A., Mortimore, R.N., Vila, J.-L., 2004. Multiscale fracture analysis along the French chalk coastline for investigating erosion by cliff collapse, in:

Coastal Chalk Cliff Instability, Geological Society Engineering Geology Special Publication. Mortimore R.N. and Duperret A., pp. 57-74.

Gilham, J., Barlow, J., Moore, R., 2018. Marine control over negative power law scaling of mass wasting events in chalk sea cliffs with implications for future recession under the UKCP09 medium emission scenario. Earth Surf. Process. Landf. 43, 2136-2146. https://doi.org/10.1002/esp.4379

Griggs, G.B., Trenhaile, A.S., 1994. Coastal cliffs and platforms, in: Coastal Evolution. Carter R.W.G. and Woodroffe C.D., Cambridge, pp. 425-450.

Hénaff, A., Lageat, Y., Costa, S., Plessis, E., 2002. Le recul des falaises crayeuses du Pays de Caux: détermination des processus d'érosion et quantification des rythmes d'évolution/Retreat of chalk cliffs in the Pays de Caux: processes and rates. Géomorphologie Relief Process. Environ. 8, 107-118. https://doi.org/10.3406/morfo.2002.1132 Hoyez, B., 2008. Les Falaises du Pays de Caux: lithostratigraphie des craies turonocampaniennes. Publication Univ Rouen Havre. 
Hungr, O., Leroueil, S., Picarelli, L., 2014. The Varnes classification of landslide types, an update. Landslides 11, 167-194. https://doi.org/10.1007/s10346-013-0436-y Joyal, G., Lajeunesse, P., Morissette, A., Bernatchez, P., 2016. Influence of lithostratigraphy on the retreat of an unconsolidated sedimentary coastal cliff (St. Lawrence estuary, eastern Canada). Earth Surf. Process. Landf. 41, 1055-1072. https://doi.org/10.1002/esp.3886 Kennedy, D.M., Stephenson, W.J., Naylor, L.A., 2014a. Rock coast geomorphology: A global synthesis, Geological Society. ed. Kennedy D.M., Stephenson W.J. and Naylor L.A., London. Kennedy, D.M., Stephenson, W.J., Naylor, L.A., 2014b. Introduction to the rock coasts of the world, in: Rock Coast Geomorphology: A Global Synthesis. Kennedy D.M., Stephenson W.J. and Naylor L.A., London, pp. 1-5.

Kromer, R.A., Rowe, E., Hutchinson, J., Lato, M., Abellán, A., 2017. Rockfall risk management using a pre-failure deformation database. Landslides. https://doi.org/10.1007/s10346-017-0921-9

Kuhn, D., Prüfer, S., 2014. Coastal cliff monitoring and analysis of mass wasting processes with the application of terrestrial laser scanning: A case study of Rügen, Germany. Geomorphology 213, 153-165. https://doi.org/10.1016/j.geomorph.2014.01.005 Lageat, Y., Hénaff, A., Costa, S., 2006. The retreat of the chalk cliffs of the Pays de Caux (France): erosion processes and patterns. Z. Für Geomorphol. 144, 183-197.

Laignel, B., 2003. Caractérisation et dynamique érosive de systèmes géomorphologiques continentaux sur substrat crayeux. Exemple de l'Ouest du Bassin de Paris dans le contexte nord-ouest européen.

Laignel, B., 1997. Les altérites à silex de l'ouest du Bassin de Paris: caractérisation lithologique, genèse et utilisation potentielle comme granulats ( $\mathrm{PhD}$ Thesis). Rouen. Letortu, P., Costa, S., Bensaid, A., Cador, J.-M., Quénol, H., 2014. Vitesses et modalités de recul des falaises crayeuses de Haute-Normandie (France): méthodologie et variabilité du recul. Geomorphol. Relief Process. Environ. 20, 133-144. https://doi.org/10.4000/geomorphologie.10872 
Letortu, P., Costa, S., Cador, J.-M., Coinaud, C., Cantat, O., 2015a. Statistical and empirical analyses of the triggers of coastal chalk cliff failure. Earth Surf. Process. Landf. 40, 13711386. https://doi.org/10.1002/esp.3741

Letortu, P., Costa, S., Maquaire, O., Delacourt, C., Augereau, E., Davidson, R., Suanez, S., Nabucet, J., 2015b. Retreat rates, modalities and agents responsible for erosion along the coastal chalk cliffs of Upper Normandy: The contribution of terrestrial laser scanning.

Geomorphology 245, 3-14. https://doi.org/10.1016/j.geomorph.2015.05.007

Letortu, P., Jaud, M., Grandjean, P., Ammann, J., Costa, S., Maquaire, O., Davidson, R., Le Dantec, N., Delacourt, C., 2018. Examining high-resolution survey methods for monitoring cliff erosion at an operational scale. GIScience Remote Sens. 55, 457-476. https://doi.org/10.1080/15481603.2017.1408931 Lim, M., 2014. The rock coast of the British Isles: cliffs, in: Rock Coast Geomorphology: A Global Synthesis. Kennedy D.M., Stephenson W.J. and Naylor L.A., London, pp. 19-38. Lim, M., Rosser, N.J., Petley, D.N., Keen, M., 2011. Quantifying the controls and influence of tide and wave impacts on coastal rock cliff erosion. J. Coast. Res. 27, 46-56. https://doi.org/10.2112/JCOASTRES-D-09-00061.1 May, V.J., Heeps, C., 1985. The nature and rates of change on chalk coastlines. Z. Für Geomorphol. 57, 81-94.

Mégnien, C., Mégnien, F., 1980. Synthèse géologique du Bassin de Paris, Mémoire du Bureau des Recherches Géologiques et Minières. ed.

Michoud, C., Carrea, D., Costa, S., Derron, M.H., Jaboyedoff, M., Delacourt, C., Maquaire, O., Letortu, P., Davidson, R., 2014. Landslide detection and monitoring capability of boatbased mobile laser scanning along Dieppe coastal cliffs, Normandy. Landslides 12, 403-418. https://doi.org/10.1007/s10346-014-0542-5

Middlemiss, F.A., 1983. Instability of Chalk cliffs between the South Foreland and Kingsdown, Kent, in relation to geological structure. Proc. Geol. Assoc. 94, 115-122.

Mortimore, R.N., 2001. ROCC project, Report on mapping of the chalk Channel coast of France from Port du Havre-Antifer to Ault. BRGM. 
Mortimore, R.N., Lawrence, J., Pope, D., Duperret, A., Genter, A., 2004a. Coastal cliff geohazards in weak rock: the UK Chalk cliffs of Sussex, in: Coastal Chalk Cliff Instability, Geological Society Engineering Geology Special Publication. Mortimore R.N. and Duperret A., London, pp. 3-31.

Mortimore, R.N., Stone, K.J., Lawrence, J., Duperret, A., 2004b. Chalk physical properties and cliff instability, in: Coastal Chalk Cliff Instability, Geological Society Engineering Geology Special Publication. pp. 75-88.

Moses, C.A., Robinson, D.A., Williams, R.B.G., Marques, F.M.S.F., 2006. Predicting rates of shore platform downwearing from rock geotechnical properties and laboratory simulation of weathering and erosion processes. Z. Geomorphol. Suppl. 144, 19-37.

Naylor, L.A., Stephenson, W.J., Trenhaile, A.S., 2010. Rock coast geomorphology: Recent advances and future research directions. Geomorphology 114, 3-11. https://doi.org/10.1016/j.geomorph.2009.02.004

Pomerol, B., Bailey, H.W., Monciardini, C., Mortimore, R.N., 1987. Lithostratigraphy and biostratigraphy of the Lewes and Seaford chalks: A link across the Anglo-Paris Basin at the Turonian-Senonian boundary. Cretac. Res. 8, 289-304.

Pomerol, C., Feugueur, L., 1986. Histoire géologique du Bassin de Paris, Mémoires du Muséum national d'histoire naturelle. ed.

Prêcheur, C., 1960. Le littoral de la Manche, de Sainte-Adresse à Ault: étude morphologique. Poitiers: SFIL.

Regard, V., Dewez, T., Bourlès, D.L., Anderson, R.S., Duperret, A., Costa, S., Leanni, L., Lasseur, E., Pedoja, K., Maillet, G.M., 2012. Late Holocene seacliff retreat recorded by $10 \mathrm{Be}$ profiles across a coastal platform: Theory and example from the English Channel. Quat. Geochronol. 11, 87-97. https://doi.org/10.1016/j.quageo.2012.02.027 Rohmer, J., Dewez, T., 2013. On the deviation of extreme sea-cliff instabilities from the power-law frequency-volume distribution: Practical implications for coastal management. J. Coast. Res. 1698-1703. https://doi.org/10.2112/SI65-287 
800

801

802

803

804

805

806

807

808

809

810

811

812

813

814

815

816

817

818

819

820

821

822

823

Rosser, N., Lim, M., Petley, D., Dunning, S., Allison, R., 2007. Patterns of precursory rockfall prior to slope failure. J. Geophys. Res. Earth Surf. 112.

https://doi.org/10.1029/2006JF000642

Royán, M.J., Abellán, A., Jaboyedoff, M., Vilaplana, J.M., Calvet, J., 2014. Spatio-temporal analysis of rockfall pre-failure deformation using Terrestrial LiDAR. Landslides 11, 697-709. https://doi.org/10.1007/s10346-013-0442-0

Sajinkumar, K.S., Kannan, J.P., Indu, G.K., Muraleedharan, C., Rani, V.R., 2017. A composite fall-slippage model for cliff recession in the sedimentary coastal cliffs. Geosci. Front. 8, 903-914. https://doi.org/10.1016/j.gsf.2016.08.006

Sunamura, T., 1992. Geomorphology of Rocky Coasts. John Wiley \& Sons.

Swenson, M.J., Wu, C.H., Edil, T.B., Mickelson, D.M., 2006. Bluff recession rates and wave impact along the Wisconsin coast of Lake Superior. J. Gt. Lakes Res. 32, 512-530.

https://doi.org/10.3394/0380-1330(2006)32[512:BRRAWI]2.0.CO;2

Trenhaile, A.S., 2002. Rock coasts, with particular emphasis on shore platforms.

Geomorphology 48, 7-22. https://doi.org/10.1016/S0169-555X(02)00173-3

Trenhaile, A.S., 1987. The geomorphology of rock coasts. Oxford University Press, Incorporated.

Varnes, D.J., 1978. Slope movement types and processes, in: Landslides: Analysis and Control. Washington, pp. 11-33.

Viles, H.A., 2012. Linking weathering and rock slope instability: non-linear perspectives.

Earth Surf. Process. Landf. 38, 62-70. https://doi.org/10.1002/esp.3294

Young, A.P., 2018. Decadal-scale coastal cliff retreat in southern and central California.

Geomorphology 300, 164-175. https://doi.org/10.1016/j.geomorph.2017.10.010 